\title{
The Effect of Reference Point Prices on Mergers and Acquisitions
}

\section{Citation}

Baker, Malcolm, Xin Pan, and Jeffrey Wurgler. "The Effect of Reference Point Prices on Mergers and Acquisitions." Journal of Financial Economics 106, no. 1 (October 2012): 49-71.

\section{Published Version}

http://www.sciencedirect.com/science/article/pii/S0304405X12000712

\section{Permanent link}

http://nrs.harvard.edu/urn-3:HUL.InstRepos:16388195

\section{Terms of Use}

This article was downloaded from Harvard University's DASH repository, and is made available under the terms and conditions applicable to Open Access Policy Articles, as set forth at http:// nrs.harvard.edu/urn-3:HUL.InstRepos:dash.current.terms-of-use\#OAP

\section{Share Your Story}

The Harvard community has made this article openly available.

Please share how this access benefits you. Submit a story.

Accessibility 


\title{
The effect of reference point prices on mergers and acquisitions ${ }^{*}$
}

\author{
Malcolm Baker \\ Harvard Business School and NBER \\ mbaker@hbs.edu \\ Xin Pan \\ Harvard University \\ xinpan@fas.harvard.edu \\ Jeffrey Wurgler \\ NYU Stern School of Business and NBER \\ jwurgler@stern.nyu.edu
}

June 15, 2011

\begin{abstract}
We study the relationship between the target's recent peak prices and several aspects of merger and acquisition activity including offer prices, deal success, market reaction, and merger waves. Offer prices are biased toward the target's recent peak prices although such prices are economically unremarkable. The offer's probability of acceptance jumps discontinuously when it exceeds a peak price, a real effect of the use of peak prices. Conversely, bidder shareholders react more negatively as the offer price is influenced upward toward a peak price. Merger waves occur when high recent returns on the stock market and on likely targets make it easier for bidders to offer a peak price. The results are consistent with the use of recent peak prices as reference points or judgmental anchors for purposes of valuation.
\end{abstract}

\footnotetext{
* For helpful comments we thank the Honorable William Allen, Yakov Amihud, Nick Barberis, Lauren Cohen, Ravi Dhar, Ming Dong, Robin Greenwood, Steven Huddart, Ulrike Malmendier, Florencia Marotta-Wurgler, Steven Mintz, Daniel Paravisini, Gordon Phillips, Gerald Rosenfeld of Rothschild North America, Rick Ruback, Meir Statman, Joshua White, Russ Winer, and seminar participants at Columbia University, Harvard Business School, Michigan State, the NBER Corporate Finance Summer Institute, NYU Stern, the Rising Star Conference at RPI, and the Securities and Exchange Commission. Baker gratefully acknowledges financial support from the Division of Research of the Harvard Business School.
} 


\section{Introduction}

The price that a bidding firm offers for a target is generally the outcome of a negotiation with the target's board. The standard textbook story emphasizes synergies. The offer price starts with an estimate of the increased value of the combined entity under the new corporate structure, deriving from cost reductions in labor or capital equipment, supply chain reliability, debt tax shields, market power, market access and expertise, improved management, internal finance, and other economic factors (e.g., Lang, Stulz, and Walkling (1989) or Jovanovic and Rousseau (2002)). This value gain is then divided between the two entities' shareholders according to their relative bargaining power. In theory, the textbooks suggest, all of this leads to an objective and specific price for the target's shares.

In practice, valuing a company is subjective. A large number of assumptions are needed to justify any particular valuation of the combination. ${ }^{1}$ In addition, relative bargaining power may not be fully established. Boards can bluff in the negotiation. Other bidders may emerge. These real-life considerations mean the appropriate target price cannot be set with precision, but established only to be within a broad range. We hypothesize that this indeterminacy, in turn, creates space for the price offered and its reception to reflect other influences, in particular the psychological influences on the board of the target and the bidder and target shareholders, who ultimately must approve the price.

In particular, we propose that salient but largely irrelevant reference point stock prices of the target play roles in merger and acquisition activity through both the prices and the types and quantities of firms traded. This psychological motivation has well-established roots in the anchoring-and-conservative-adjustment estimation method (Tversky and Kahneman (1974)), the salience of initial anchor positions in negotiations, and the prospect theory tenet that the utility of an outcome is a function of the outcome's distance from a reference point.

The reference point stock prices that we focus on are the peak prices that the target has achieved over various horizons, such as the 13-week high, 26-week high, and so on. The 52week high price, for example, is routinely reported and discussed in the financial press and is salient to executives, boards, and investors. Importantly, and in contrast to target shareholders' individual cost bases, which represent other natural reference point prices for individuals, these

\footnotetext{
${ }^{1}$ Those who teach valuation analysis in business schools are painfully familiar with this fact.
} 
peak prices are reference prices that are common across stakeholders. We start with some anecdotes that suggest that practitioners do indeed give special weight to recent peak prices in target valuations: Target firm boards that are discouraging the deal often point out that the bid is below the recent high, while those that are encouraging the deal often note when the bid compares favorably with that price.

We start by considering the relationship between recent peak prices and the offer price. Our results show a visually and statistically obvious effect of recent peak prices. Histograms of offer prices show spikes at the 13-week high, 26-week high, 39-week high, 52-week high, and 104-week high. In other words, a peak price often serves not merely as a subtle psychological anchor but as one sufficiently heavy that there is no "adjustment” from it at all.

These peak prices are of incremental importance to the offer price decision. Controlling for the 13-week high, the 26-week high price has a statistically and economically significant effect on offer prices, and the 39- and 52-week high prices also have independent explanatory power. Having documented that multiple reference points matter, we focus on the 52-week high for simplicity. For 52-week highs of a typical size, a $10 \%$ increase in the 52-week high is associated with a $3 \%$ increase in the offer premium.

The effect of peak prices on offer prices survives a variety of control variables, robustness tests, and falsification tests. We examine the 52-week high's effect on offer prices in various subsamples and consider non-psychological alternative explanations. Most notably, the 52-week high could be proxying for the objective, but unobserved value gain from combination. That is, it is the value to which the target assets could return if only they were managed as well by the bidder in the future as they were by the target in the past. This agency- or informationbased hypothesis should perhaps be regarded as the null hypothesis. However, we find that the 52-week high of the market index also has a strong effect on offer prices. Because the market component of the target's 52-week high cannot be recovered merely by changing management, this hypothesis cannot, at least not fully, explain the 52-week high effect on offer prices.

The second dimension of merger activity we consider is deal success — what distinguishes bids that succeed from those that fail, and in particular whether the offer price's relationship to peak prices plays a role. Not surprisingly, higher offer prices are associated with higher probabilities of deal success; we control for this effect with a fourth-order polynomial of offer prices. The interesting finding is that an additional dummy variable indicates that the probability 
of deal success increases discontinuously by $3 \%$ to $4 \%$ when the bidder makes an offer price even slightly above the target's 52-week high.

Bidder announcement effects have been extensively studied. One hypothesis is that they include the market's estimate of overpayment. The offer premium itself is not a clean measure of overpayment, however, as better combinations may attract higher offer premia. The 52-week high is an ideal instrument for the effects of overpayment in mergers and acquisitions, separate from synergies or misvaluation in the bidder. We find that the bidder's announcement effect becomes more negative with the target's distance from its 52-week high. The bidder announcement effect is $2 \%$ to $3 \%$ worse for each $10 \%$ increase in the component of offer premium that is explained by the 52-week high. Given the strong connection between 52-week highs and offer prices, an interpretation is that shareholders of the bidder may view the bidder as more likely to be overpaying when the target has fallen far below this reference price.

Apart from its impact on deal success and the value transfer in successful deals, high peak prices may deter bidders from appearing in the first place. The fourth and last aspect of merger activity that we examine is merger waves. It is well known that merger waves coincide with higher recent returns and stock market valuations. The potential link to reference price peaks is that higher market valuations mean that more targets are trading closer to their peak prices. Therefore, these reference points may become easier to satisfy (from the perspective of targets) and to justify (from the perspective of bidders) when valuations are high than when they have fallen. In this section, we use time-series data and so our tests are less refined. Not surprisingly, we find that the market's 52-week high relative to its current value is inversely related to the level of merger activity. More interesting is that the 52-week high matters controlling for the past twelve individual monthly returns. The effects are somewhat stronger using the 52-week high premium on firms that ex ante have typical characteristics of targets. A comprehensive study of merger waves is beyond our scope; these results should be characterized as preliminary evidence that the use of peak prices plays a role in merger waves.

To summarize, the use of reference point prices in mergers and acquisitions may shed light on phenomena that standard theories don't fully explain. The most obvious is that they help to explain offer premia in a novel and economically significant fashion. The deal success and market reaction implications of reference points are also somewhat unique. There are several explanations for why merger volume and stock market valuations mover together, however, such 
as the market timing theories of mergers by Shleifer and Vishny (2003) and Rhodes-Kropf and Viswanathan (2004); our results provide an additional explanation. Reference points don't shed light on the nature of deal synergies, although nor do market timing, agency, or overconfidence theories. Jovanovic and Rousseau's (2002) Q-theory considers mergers as vehicles for technology transfer and capital reallocation, addressing the market valuations-merger waves link and incorporating a synergies story, but few other aspects of merger activity that we study. ${ }^{2}$ Jensen's (1986) agency theory has few overlapping predictions with reference points, nor do the managerial theories of Amihud and Lev (1981) and Morck, Shleifer, and Vishny (1990) or the overconfidence views of Roll (1986), Ben-David, Graham, and Harvey (2007), and Malmendier and Tate (2008). ${ }^{3}$ An interesting difference between the reference point thinking and merger theories is that reference points embrace considerations of the target, rather than focus on the bidder alone or features of the combination. Of course, these are broad generalizations, and the literature on mergers and acquisitions is vast—see Betton, Eckbo, and Thorburn (2008) for a comprehensive survey.

Section II proposes some hypotheses based on the anchoring and adjustment phenomenon and briefly reviews related scientific and anecdotal evidence. Section III reviews the basic data. Sections IV, V, VI, and VII report how reference points affect offer prices, deal success, offer announcement effects, and merger waves, respectively. Section VIII concludes.

\section{The Psychology of Reference Points, Loss Aversion, and Anchoring and Adjustment}

The psychology of pricing is a recognized subfield of marketing research. There, the focus is on identifying prices or "price points" that lead to discontinuous jumps in demand. The M\&A context has several parallels. The bidder wants to offer the lowest price that the target will accept: the target is the consumer to whom the bidder markets.

Unlike in retail pricing, of course, the target shareholders in a merger transaction are selling not buying. The bidder is therefore looking for announced price points that will lead to discontinuous jumps in supply. We briefly review some of the psychology and economics relevant to the use of reference point prices.

\footnotetext{
${ }^{2}$ See also Maksimovic and Phillips (2001), Maksimovic, Phillips, and Prabhala (2008), Rajan, Volpin, and Zingales (2000), and chapters in Kaplan (2000) on synergies and value enhancements.

${ }^{3}$ Baker, Ruback, and Wurgler (2007) survey behavioral theories of mergers (not including reference points) and Andrade and Stafford (2004) review non-behavioral theories.
} 


\section{A. Reference Points, Loss Aversion, and Anchoring and Adjustment}

The empirically-motivated prospect theory of Kahneman and Tversky (1979) identifies a departure from preference specifications that emphasize levels of goods and wealth as the sole drivers of value or utility. Their theory holds that changes in status relative to particular reference points are also a carrier of perceived value. The reference point in their theory is derived from the context at hand. It may be influenced by normatively-irrelevant frames of reference, or it may be based on an aspirational level or expectation as opposed to the status quo (Kahneman (1992)).

Another component of preferences that Kahneman and Tversky emphasize is loss aversion. This refers to a kink in prospect theory's value function at its origin, specifically that losses are disliked more than equal-size gains are liked. Furthermore, they set the shape of their theory's value function to include convexity in the domain of losses and concavity in gains to help it explain finer features of observed choice. To summarize, their value function is shaped like a kinked "S" and is defined over changes in value relative to a reference point.

The related phenomenon of anchoring and adjustment is associated with Tversky and Kahneman (1974). It refers to a belief formation process (not a utility perception) under which one begins at a specific initial value, salient but perhaps entirely irrelevant, and then adjusts toward a final estimate based on other considerations. The bias typically observed is that the final estimate is insufficiently adjusted from the initial value, hence its term "anchor." The bias may be used to advantage in negotiations. Kahneman (1992) notes that "negotiators commonly have an interest in misleading their counterpart about their reservation prices.... High claims and low offers are therefore made in the hope of anchoring the other side's view of one's true position.... The moral of studies of anchoring is that such efforts at deception can succeed ... even when these messages are neither accepted nor even believed” (p. 309-310).

Economic applications of these ideas are plentiful. Neale and Bazerman (1991) consider the setting of union negotiations over wages and review strategems that appear to take advantage of the anchoring phenomenon. Babcock, Wang, and Loewenstein (1996) similarly report on the self-serving use of comparison groups as reference points in wage bargaining. Camerer and Malmendier (2007) consider reference point effects in organizational economics generally. Northcraft and Neale (1987) show that the asking price affects estimates of the value of a house, even among professional real estate agents who claim to view it as uninformative; but List (2004, 
2005) and Plott and Zeiler (2005) qualifies this with evidence that experience attenuates or eliminates the endowment effect. ${ }^{4}$ Genesove and Mayer (2001) find that homeowners' cost bases significantly affects negotiations and thus outcomes of real estate transactions. The large literature on money illusion is based centrally on nominal reference point pricing.

The use of reference points among investors and other financial actors appears, for example, in Shefrin and Statman (1985), who note that prospect theory and loss aversion imply that investors have a "disposition effect" and are reluctant to sell stocks showing paper losses. This effect is in Odean (1998), Grinblatt and Keloharju (2001), Grinblatt and Han (2005), Ivkovich, Poterba, and Weisbenner (2005), and Birru (2009). ${ }^{5}$ Shefrin and Statman (1984) suggest a view of dividends based on loss aversion and framing effects. Barberis, Huang, and Santos (2001) discuss asset pricing implications of prospect theory, and Barberis and Xiong (2009) emphasize that the 52-week high is a price where investors are particularly willing to realize gains. DeGeorge, Patel, and Zeckhauser (1999) show that executives strain to exceed salient EPS thresholds. Baker and Xuan (2009) find that the price at which the CEO joined the company is a reference point for raising new equity. Loughran and Ritter (2002) propose that reference-point preferences and mental accounting help to explain IPO underpricing, a view tested by Ljungqvist and Wilhelm (2005). Hart and Moore (2008) develop contracting theory based on parties' use of anchoring and psychological reference points.

Certain of these actions are efforts to cater to investors who notice reference points such as earnings per share and 52-week highs_-for example, Huddart, Lang, and Yetman (2009) find stock market volume and price effects around this reference stock price, and Heath, Huddart, and Lang (1999) find that employee exercise of stock options doubles when their company's stock price exceeds its 52-week high.

\section{B. The Target}

In a sufficiently large merger or acquisition, the transaction must be approved by the management and shareholders of the target as well as those of the bidder. We start by discussing

\footnotetext{
${ }^{4}$ In this connection, it is noteworthy that most executives and investors are not involved in merger transactions with any frequency, although their bankers may be.

${ }^{5}$ In unreported tests we considered the trading volume-weighted average price (e.g. Grinblatt and Han (2005)) as another reference price that may be relevant to merger activity. However, perhaps because of the inherent noisiness of our measure, as well as the fact that it pertains exclusively to target shareholders rather than a wider range of stakeholders, we found weaker results than those for the 52-week high.
} 
empirical hypotheses that derive from the psychology outlined above. The most obvious application involves the disposition effect, or the reluctance to realize losses relative to a reference point. While for some investors the reference point is likely to be their purchase price, i.e. the disposition effect documented in papers mentioned above, other important reference points - and, importantly for our purposes, ones that are common across shareholders - are the firm's recent peak prices. The 52-week high price, for example, is widely reported in the financial media. Furthermore, because it by definition is a fairly recent price, it seems attainable by target shareholders even in the absence of a merger. This logic predicts that targets are more likely to approve mergers in which the offer price approaches or exceeds a recent peak price. More subtly, the S-shaped value function predicts that the further is the current price from a recent high, the less influence the marginal dollar away from that reference will have in terms of the perception of losses.

Belief formation via anchoring and adjustment may reinforce the utility effects - and at least three levels, two psychological and one practical. First, target shareholders must form an estimate of target value when deciding whether to accept the offer. Lacking time, information, and ability to accurately compute present values of future cash flows under alternative ownership and management scenarios, some of them will consult recent peak prices as references. Second, targets seek and attempt to justify the highest possible price. Whether or not the target board views it as relevant, a recent peak price can be used as a negotiating anchor. The 52-week high may be the highest salient and specific price at hand. Third, the target's management and board faces a risk of shareholder litigation if they recommend selling at a price that is viewed as too low. That they did not sell below a recent peak price provides some rhetorical cover.

\section{The Bidder}

The bidder's psychology can also be affected by anchoring and adjustment both directly and strategically. When pursuing a target, the bidder has to decide how much it is willing to pay, and that in turn depends on how it values the target. It is not possible to pin this down with certainty. An input to this estimation must be the target's recent valuations, and as such its own recent peak prices may enter as anchors. The bidder may reason, if the target was valued at a certain level just a few months ago, shouldn't we, with our ability to realize synergies, value it 
near or above that same level? Thus a peak price can become an anchor, and as mentioned above insufficient adjustment from that level becomes the norm.

Reinforcing predictions arise from the fact that bidder management must justify their offer to shareholders and financiers. The management may reassure such stakeholders with the simple argument that the target was worth that price in the past and so, of course, it must be possible to realize that in the future. On the other hand, if the bidder's investors do not think as hard as its board about the target's potential valuation, they may be less biased by the anchoring phenomenon and so more likely to view peak-price-driven bids as overpaying.

And there is the bidder's perception of the target's psychology. Once a target valuation is established by any means, the bidder must estimate the minimum price that the target will accept. Boards may predict that the target's 52-week high will be used both as a strategic anchor against them in negotiations and as a reference point that their own investors care about. ${ }^{6}$ Or, bidders may appreciate that targets want a "fair" offer and, knowing that targets have a biased notion of fairness (Babcock et al. (1995)), offer a recent peak price even if they view it as too high.

\section{Anecdotes from Shareholder Communications}

The 52-week high price is often cited in communications between managements and shareholders about pending mergers or acquisitions. It is also cited by the media as a simple yardstick with which to put the bid price in context. We mention three anecdotal examples here; the remainder of the paper provides a large sample analysis, but cannot provide as much color.

The management of Taro Pharmaceutical Industries, in a July 28, 2008, amendment to its SEC SC 14D-9 filing recommending against the tender offer from Sun Pharmaceutical Industries, made the following statement: "Beyond what was written in the 14D-9, I would add only the obvious: that Sun’s offer of $\$ 7.75$ per share is significantly below the price at which our shares are trading today, which is at a 52-week high, and even further below the price that Sun paid to get blocks of Taro shares in recent private transactions with investors. Given our performance year to date and our outlook, I believe the Sun offer significantly undervalues our Company and deprives you of what we believe your shares are worth.” Left unmentioned is the fact that Sun's bid itself contributed to Toro’s high price today.

\footnotetext{
${ }^{6}$ In an interview with one of the authors, Gerald Rosenfeld, CEO of the investment bank Rothschild North America, stated that in his experience the target's current price is the most important reference for valuation while the 52week high is the second-most critical reference.
} 
The media often reinforce these claims. For example, on February 1, 2008, the Wall Street Journal reported, “Microsoft's \$31-per-share offer - \$44.6 billion - represented a 62 percent premium to Yahoo's closing price late Thursday, although it's below Yahoo's 52-week high of \$34.08 reached less than four months ago.” The article failed to explain why an historical price more than 78\% higher than the current price should be relevant, however.

The 52-week high can of course also be cited as reason to embrace, not reject, an offer. Figure 1 shows an example slide from a shareholder presentation by Cablevision to its shareholders on October 24, 2007. In arguing for acceptance of the offer from the family which already controlled the company, Cablevision management highlights the fact that the bid price is at a premium to a variety of 52-week high and low prices, an appeal both to anchoring as an estimate of value and reference point utility.

These anecdotes give some suggestive color to the salience of reference points to target agents and the media and the contexts in which they are employed. It is precisely because reference point prices may affect many stakeholders in a merger transaction—advisors, boards, and investors and financiers of both the bidder and the target - that we focus the empirical work on documenting the effects of reference point prices on specific merger outcomes. In other words, the odds of success in our empirical work increases from the numerous overlapping and reinforcing predictions noted above. At the same time this makes it difficult to provide a full attribution of our results to particular psychological mechanisms and negotiating strategies.

\section{Data}

\section{A. Merger and Acquisition Sample}

The sample of deals is described in Table 1. Our source for mergers and acquisitions is Thomson Financial. We start with all unique deals (unique bids) where the announcement date is between January 1, 1984, and December 31, 2007, where the target is a public company, where the offer price is not missing, and where the bidder purchased at least $85 \%$ of the target firm shares outstanding or else the percentage acquired is unknown. We exclude deals that are missing an offer price or have been classified by Thomson as recapitalizations, repurchases, rumors, or target solicitations. These constitute the minimal set of exclusions required for our analysis. Of these deals, we were able to compute the target's 52-week high price from CRSP for a final sample of 7,498. 
We define the offer premium as the total consideration offered scaled by the target's price as of 30 days prior to the announcement. Similarly, the 52-week target (market index) high is the 52-week high stock price (market index) over the 365 calendar days ending 30 days prior to the announcement date expressed as a percentage difference from the CRSP stock price (market index) 30 calendar days prior to the announcement date. The CRSP market index is formed using total market value-weighted returns. The purpose of scaling these prices by a common factor is to eliminate heteroskedasticity that would result from comparing them in raw form. The purpose of choosing a 30-day lagged price as this scaling factor is to attenuate any upward rumors or new information effect on the offer premium. See Schwert (1996) for the relationship between offer premia and pre-offer price runups.

For all deals, Thomson gives information on whether the offer is a tender offer and whether the bidder is a financial buyer (LBO). For a subset of deals, we have information on the form of payment is cash, stock, or other, whether the deal is completed or withdrawn, and whether the bidder attitude is hostile, friendly, or neutral. Data on the form of payment and attitude of the deal are not available before 1990, but we are able to determine the form of payment for 4,361 deals and attitude for 4,346 deals, 220 of which were hostile. Of our main sample, 1,522 are tender offers and 192 are acquisitions by financial firms. It is likely that Thomson is underreporting these deals, particularly the frequency of leveraged buyouts in recent years. We keep track of the success of specific offers, not whether the target is ultimately acquired. Like Betton and Eckbo (2000), we are concerned with all bids, from the first to the last. Of the 6,926 deals that Thomson records as either completed or withdrawn, 26\% are withdrawn. Of course, this includes situations where a competing or revised offer emerged, so the rate of overall success is much higher than these averages would indicate.

\section{B. Summary Statistics}

Table 2 reports means, standard deviations, medians, and extreme values for deal pricing, outcome variables, and control variables. Regarding prices, the median offer premium is $29.4 \%$, the median 13-week high target price is $9.34 \%$, etc. Peak prices increase monotonically with horizon, reaching a median of $30.10 \%$ over the past two years. The median 52-week high market price is 3.2\%. These are all expressed in log terms. For the peak prices, which of course are positive by definition, we Winsorize at the 1\% and $99 \%$ levels, but wide variation remains. 
In addition to the primary variables of interest, we record secondary deal outcome variables in Panel B, and deal, target, and bidder characteristics in Panel C. All continuous variables among these are also Winsorized. We calculate the three-day announcement return of the bidder by compounding the daily holding period return from CRSP (CRSP: RET) centered on the announcement date from Thomson. The median is $-0.81 \%$. About $74 \%$ of the offers are successfully completed.

The target and bidder characteristics are from standard sources. Return on equity is defined as net income (Compustat: NI) divided by shareholders' equity (Compustat: SEQ). The return on assets is defined as net income (NI) divided by total assets (Compustat: AT). The bookto-market ratio is defined as book equity divided by market equity, where book equity is total shareholders' equity (Compustat: SEQ) plus deferred taxes and investment tax credit (Compustat: TXDITC) minus the redemption value of preferred stock (Compustat: PSRKRV) and market equity is calculated by multiplying shares outstanding (CRSP: SHROUT) and price (CRSP: PRC) at fiscal year end. The earnings price ratio is defined as earnings before interest and taxes (Compustat: EBIT) divided by market equity (ME). Because not all target and bidder companies within the main sample of 7,498 deals were tracked by Compustat in the year before the announcement of the deal, we have financial ratios of the target for only 5,108 deals and of the bidder for only 2,048 deals.

The price volatility, two-month return, and one-year return of the target are from CRSP. Volatility is defined as the standard deviation of daily returns for the 365 calendar days ending 30 days prior to the announcement date. Returns are calculated by compounding the daily holding period return (CRSP: RET) for the appropriate period ending 30 days prior to the announcement date. Market capitalization is price (CRSP: PRC) times shares outstanding (CRSP: SHROUT) from CRSP at the fiscal year end prior to Thomson's announcement date.

Panel C of Table 2 summarizes the our battery of controls. Over the sample period, $43 \%$ of the deals are financed with cash, 33\% are financed with stock, $20 \%$ are tender offers, $5 \%$ are hostile, and 3\% are acquired by financial firms. As one would expect, targets are generally financially weaker than bidders, including in valuation ratios with targets relatively more likely to be value firms. One explanation is, of course, that poorly-managed firms become targets (e.g., Lang and Stulz (1984) and Mitchell and Lehn (1990)). 


\section{Bid Prices}

\section{A. Basic Results}

We begin by documenting the effect of past peak prices on offer prices, because this relationship is central to the reference point perspective. Figure 2 simply plots the density of offer prices relative to the 13-, 26-, 39-, 52-, and 104-week highs. To keep the scale of the x-axis manageable, we do not plot offer premia that exceed 500\% in absolute value.

The plots show clear spikes at the 13-week high, 26-week high, 39-week high, 52-week high, and 104-week (two-year) high. The first price is weakly less than the second, which is weakly less than the third, and so on, so we will use regressions to verify the incremental importance of peaks at each horizon. What the figures are able to prove on their own is that it is common to offer exactly a recent peak price. To be clear, these peaks are not mechanically related to the offer price setting its own peak price, because the most recent peak price we allow is 30 days before the offer's announcement. Whether a price is at or simply very close to the 52week high is not important economically. ${ }^{7}$ The takeaway from Figure 2 is that peak prices play specific roles, consistent with stories involving reference dependence.

Figure 3 presents a formal discontinuity analysis of the 52-week high (for brevity we focus on a single peak). Not only is the modal outcome equal to the 52-week high, but now another feature is revealed, which is that many other offers tend to collect just above the 52-week high. This is most apparent when we divide offers into fewer bins in Panel B. This jump in the distribution is statistically significant, with a p-value of 0.01 or less. ${ }^{8}$ Panel A shows yet another interpretable feature. There is a slight decline in the density as we approach the 52-week high from below, and a surge as we pass it. Some bidders may reason that if they were already considering a bid around this level, they may as well push it to just above the 52-week high to increase the likelihood of acceptance-and this actually works, as we show later on. ${ }^{9}$

\footnotetext{
${ }^{7}$ Actually, in our later analysis of the probability of offer acceptance, we find that even tiny differences in offer prices can affect economic outcomes.

${ }^{8}$ One concern is whether the discontinuity reflects discreteness in prices. Shares are quoted in sixteenths, eighths, and decimals in our sample. The 52-week high is a price that has been observed in the price history of the target, so it falls on what might naturally be a mass point. A few refined show that this is not driving our discontinuity results. A discontinuity is apparent even when we drop the bin that contains the 52-week high. The p-value is 0.016 in Panel A and below 0.000 in Panel B. We have also estimated a bootstrap p-value by computing z-statistics for discontinuities around randomly chosen past target stock prices. Using this distribution, we find a p-value of 0.013 .

${ }^{9}$ One question is why any bidder would locate just below the 52-week high. This could reflect the bidder's anticipation of a difficult negotiation and the preservation of a psychological "option value” of being able to cross a salient threshold as a "concession" in later rounds. Alternatively, mass here may be the result of stock deals-cash deals would have a more uneven mass on the left and right sides of the distribution; we study cash and stock deals
} 
The vast majority of offer prices of course do not equal the 52-week high. We examine the overall shape of the relationship between these prices nonparametrically in Figure 4 . We estimate Gaussian kernel regressions of the model

$$
\text { Offer }_{i t}=a+b 52 \text { WeekHigh }_{i, t-30}+e_{i t}
$$

with varying bandwidths and estimation points.

Both panels in the figure suggest that the offer premium rises by approximately 3 to $3.5 \%$ with every $10 \%$ increase in the 52-week high. Panel A limits the sample to situations where the 52-week high is less than 50\% higher than the pre-offer price. Beyond this level, with a long right tail and limited data, the estimated incremental effect of the 52-week high is much noisier and both statistically and economically weaker, as shown in Panel B. This might be consistent with the shape of the prospect theory value function—as "losses" increase, the marginal pain of additional loss decreases, so target shareholders may acquiesce more easily. Or, in a quasirational argument, targets that have fallen substantially from their 52-week high may fail to persuade the bidder of its relevance.

The first columns of Table 3 report least-squares estimates of Eq. (1) and, with the nonlinearity of Figure 4 in mind, piecewise linear specifications:

$$
\begin{aligned}
\text { Offer }_{i t}= & a+b_{1} \min \left(52 W k H i_{i, t-30}, 25\right)+ \\
& b_{2} \max \left(0, \min \left(52 W k H i_{i, t-30}-25,50\right)\right)+b_{3} \max \left(0,52 W k H i_{i, t-30}-75\right)+e_{i t}
\end{aligned}
$$

with standard errors are clustered by month. This specification allows for a marginal effect of $b_{1}$ for 52-week high premia up to $25 \%, b_{2}$ for premia between $25 \%$ and $75 \%$, and $b_{3}$ for premia above $75 \%$. We scale the prices by the 30-day lagged price to reduce heteroskedasticity, but to the extent that investors and boards don't think of these prices in terms of the 30-day lagged price, this practice can also lead to a type of measurement error that induces a spurious positive correlation. We therefore include the inverse of the 30-day lagged price in all specifications.

The simple linear specification shows that offer prices rise about $1 \%$ for every $10 \%$ rise in the 52-week high. This is statistically significant but not large. The true size of the effect is masked by large outliers in the independent variable, which even when Winsorized includes observations with values exceeding 250\%. The piecewise linear specifications address this. They show a magnitude similar to that suggested in Figure 4, with a 10\% higher 52-week high by chance be near the 52-week high. In any case, such behavior is likely to make the outcome effects here weaker. 
effecting a roughly 3.3\% higher offer price over the typical range of 52-week highs. As the 52week high reference price exceeds 25\%, however, it exerts a smaller influence, rising at $1.1 \%$ for each additional 10\% increase in the 52-week high between 25\% and 75\%. Beyond 75\%, the effect is approximately $0.7 \%$. This pattern is consistent with the S-shaped value function of prospect theory, which implies that the further is the current price from the reference point, the less the marginal perceived loss. However, there are other explanations.

The remaining columns test whether there is a specific interval over which peak prices affect offer prices or whether peaks over several intervals have incremental explanatory ability. We start with the 13-week high as a baseline regressor and add "incremental" high regressors at 13-week intervals until we reach back two years from the offer date. To estimate the incremental 26-week high regressor, for example, we essentially take the residual of a first-stage regression of the 26-week high on the 13-week high. However, to allow for the incremental high to have a diminishing marginal effect, we run this model three times to estimate the residual effects in cases in which the 26-week high premium is below 25\%, between $25 \%$ and $75 \%$, and above 75\%. The header to Table 3 details the empirical approach.

As Figure 2 suggested, but could not show formally, there are incremental effects of peak prices well beyond that achieved in the most recent 13 weeks. As an example, consider a hypothetical Target A whose 13-week high (ending 30 days prior to a deal announcement) is 10\% higher than the period end price. Compare this target with another Target B whose 13-week high premium is $0 \%$. All else equal, the offer price for Target $A$ will be higher than the offer price for Target B by $4.2 \%$ to $4.3 \%$ on average. Subsequent peaks have reasonably distinct effects on the offer price. Extending the example, suppose that Target A's 26-week high is 10\% higher than one would expect, in a statistical sense, given its 13-week high and Target B's 26week high is exactly what one would expect given its 13-week high. Then, the offer price for Target A would be higher by a further $2.4 \%$ to $2.9 \%$. Incremental peaks beyond 52 weeks are generally not statistically significant, with an anomaly being the incremental effect of the 78week high.

It is intuitive that long-past peaks are of progressively less relevance; the results here suggest that there is a decline after 13 weeks and then a considerable drop after 52 weeks. However, within the more recent period, a variety of peak prices matter. Having shown this, we focus on the 52-week high for the rest of the paper. We stress that this is for simplicity. There is 
plenty of analysis left to do just with one price. To repeat, there are incremental effects at horizons within 52 weeks, the 52-week high appears not to be the magic number that it appears to be in some studies of volume and stock returns.

The peak price effect does not arise just because it reflects target firm returns over a prespecified period. Table 4 adds controls for each of the twelve months ending at $t$-30.This is another effort to control for any effect of pre-offer runups on offer prices (Schwert (1996)). The peak price effects are little changed. This indicates, in another way, that it is the return since the 52-week high, i.e. the 52-week high premium, that drives the results, not that past returns were low over some fixed interval.

The last specifications in Table 4 help to evaluate a possible non-psychological alternative explanation. This explanation holds that the 52-week high price is particularly relevant because it represents a specific valuation that the bidder could hope to obtain by returning the target to "optimal" investment policy, where optimal is defined as the policies prevailing as of the time the high was reached, even in the absence of any synergies. This explanation seems inconsistent with the evidence on the importance of incremental peaks shown before. We evaluate this story further by replacing the target's 52-week high premium with the overall stock market's 52-week high. The fact that this is also a statistically and similarly economically significant predictor of offer prices casts more doubt on the alternative explanation-the bidder cannot hope to recapture the market component of the target's 52-week high by returning to a particular investment policy. While simple and brief, this test gives sharp evidence for the importance of specific reference points. Like the spikes in Figure 1, the results are not natural predictions of other theories of offer premia. We do not wish to dismiss these theories, of course. What we have shown is that peak prices play an incremental role.

If we take the sensitivity of the offer premium to the 52-week high as an arbitrary transfer of value, we can compute the total value transfer for our sample. For each the 5,135 completed deals in our sample, we multiply the 52-week high by the piecewise linear coefficients $b$ in the second column to estimate the component of the offer premium that is driven by the 52-week high. To convert this quantity to dollars, we multiply it by the target market capitalization at $t-30$ to arrive at the transfer. The total value transfer is $\$ 179$ billion, $\$ 34.9$ million per deal, or $18.0 \%$ of the total offer premium. Even under the assumption that the variation in the 52-week high is entirely arbitrary, we cannot clearly identify whether this is overpayment or underpayment 
without knowing the stand-alone fundamental value of the targets and the value of synergies from the combinations. It is possible, for example, that on average the bidder gets a good deal, but overpays when the target 52-week high is especially large relative to its current price.

\section{B. Robustness and Other Subsamples}

We report additional robustness and falsification tests in Table 5. We first examine the influence of characteristics of the proposed transaction itself-whether it is for cash, stock, hostile, a tender, or a financial bidder. Tender offers are associated with large increases in offer prices, while financial buyers are associated with lower (but still substantial) offer premia. ${ }^{10}$ These control variables do not diminish the effect of the 52-week high, nor do they increase the total regression $R^{2}$ as much as one might expect, presumably due to the relative scarcity of tenders and financial buyers in our sample. ${ }^{11}$

We examine how the 52-week high effect compares with bidder and target firm fundamentals as key inputs to offer premia. We control for seven characteristics of the bidder and the target. Large bidders bid more, while large targets receive less, as is intuitive when one considers bids in dollar terms. A notable control for purposes of robustness is the target's return volatility. This is correlated with the 52-week premium and other peaks and could reflect aspects of the target's value to the bidder. Its significance as an incremental effect is not large; on the other hand, the dummies for tender offers and financial buyers are strong in both economic and statistical significance. While some of these controls are important determinants of offer prices, their inclusion does not appear to greatly reduce the effect of peak prices.

The remaining columns conduct a falsification test. We look for a specific effect of the 52-week high in another way. We ask whether that price, as the $100^{\text {th }}$ percentile price over the past year, represents an effect distinct from the $90^{\text {th }}$ percentile price, with which it is highly correlated. The results show that despite this high correlation, the 52-week high effect comes through. Furthermore, to the extent that the $90^{\text {th }}$ percentile price also serves as an appropriate

\footnotetext{
${ }^{10}$ See DeAngelo, DeAngelo, and Rice (1984) and Kaplan (1989) for early evidence on target shareholder gains in LBOs, and Eckbo and Thorburn (2008) for a more recent survey of restructurings and LBOs.

${ }^{11}$ Heron and Lie (2006) examine the effect of 18 variables on offer premia in a sample of 526 unsolicited takeover bids. The character of their sample is different, but they also find that only a small number of factors significantly affect takeover premia (largely related to the presence of poison pills and ownership structure). The most related result is that higher target returns over the prior year are associated with lower premia. We control for lagged returns much more flexibly in Table 4, but note that their result is consistent with the negative coefficients we estimate for most lagged returns.
} 
proxy for fundamental valuation, this test, like that involving the market component of the 52week high, also casts doubt on the view that the 52-week high price effect reflects only that channel. Results are similar for the $80^{\text {th }}$, the $95^{\text {th }}$, and even the $99^{\text {th }}$ percentile of the target past stock price distribution. Taken together, the figures and tables to this point provide convincing evidence that offer prices are influenced by past peaks.

Results for a variety of subsamples are in Table 6. The first column shows that the effect is stronger in tender offers. Because a tender offer is an appeal directly to target shareholders, this reflects the perception of the bidder of the relevance of the reference point to target shareholders, as opposed to the outcome of a negotiation with the target board or its advisors. A related effect, perhaps, involves the attitude of target management. Hostile offers' prices are a bit more influenced by the 52-week high than friendly offers when the 52-week premium is relatively high. This could also relate to an effort to appeal directly to target shareholders.

Reference points have similar effects on first offer and subsequent offers. (Most offers in the sample are first offers, and indeed last offers also because most offers are successful. Be mindful that what we can observe are public first offers. Boone and Mulherin (2007) show that on the order of half of targets are sold in a competitive auction process that takes place prior to the first public offer; in other words, we often observe the outcome of that process.) The success of the offer itself, while clearly endogenous as we show later (when we study the effect of the offer price on the probability of success), provides an interesting sample split. Within the sample of successful offers, bids more strictly adhere to the 52-week high price.

The form of payment is relevant to the reference point effect, although the interpretation of the results is not unambiguous. The offer price in stock deals is more prone to reflect the 52week high when that price is relatively modest, while cash deals are more responsive to it when it is higher, in other words when the target has recently fallen more sharply. One possibility is that this reflects the communication between bidders and their cash-providing bankers. The bidders could be justifying the offer price in part on the basis of the target's recent high.

The effect is strong in both halves of the sample, but somewhat lower in the latter half. It is hard to know, but the second half result might reflect somewhat more detailed due diligence or the increasing ease of sophisticated analysis and valuation modeling. On the other hand, the effect has actually increased for medium-size 52-week high premia. Moreover, in unreported results, we consider large (above the median cap of \$100 million) and small targets separately. 
The effect is actually quite a bit stronger for large targets, including the effect of the market's 52week high. In light of the strong results both for recent years and within large firms, the empirical effects seem to be of ongoing economic importance.

\section{Deal Success}

The previous tests address the division of value between the bidding and target shareholders. Another important question is whether peak pricing affects deal success, leading to “real” economic effects via capital reallocation. While evidence exists that investor psychology affects numerous financial decisions such as corporate and mutual fund name changes, dividend policy, nominal share pricing, and financing choices, strong evidence of behavioral phenomena having real effects is not plentiful. ${ }^{12}$ A second feature of this analysis is that, like the tender offer differential in the subsamples table, it focuses on the reception of the bid by the target's management, board, investors, and advisors. It thus may identify another aspect of merger activity sensitive to anchoring and reference point utility considerations of those agents as opposed to those of the bidder.

The precision of our prediction here makes for a straightforward test for such real effects, and earlier anecdotes suggest that this is a plausible hypothesis. Suggestive of such an effect, the probability of success across our sample is $69.9 \%$ if the offer price is below the 52-week high and $76.9 \%$ if it is above. ${ }^{13}$ Table 7 tests for a discontinuity in a probit regression. Where $S=1$ if the deal is successful, we model

$$
\operatorname{pr}(S)=a+b \text { Offer }_{i t}+c\left(\text { Offer }_{i t}>52 W_{k H i} i_{i,-30}\right)+e_{i t}
$$

including control variables. ${ }^{14}$ One might expect that higher offer premia are associated with higher probabilities of success, as in e.g. Heron and Li (2006). This specification allows us to control for the level of the offer premium, unlike the cross-tab just reported, and thus to test

\footnotetext{
12 An exception is Polk and Sapienza (2009) who propose that catering to investor sentiment directly affects corporate investment.

${ }^{13}$ Bear in mind that this is the success of a particular offer, not the overall rate of success in selling the target to a given bidder.

${ }^{14}$ See Comment and Schwert (1995) and Heron and Lie (2006) for probit regressions of takeover attempt success on a wider range of control variables, such as poison pills and pension overfunding. Their samples are much smaller and of a different character. In any case, given that only two out of 18 control variables in Heron and Lie's models had p-values below 0.05, we felt that it was more important to preserve a reasonable sample size rather than require a large set of controls. It is also not clear what omitted factors would be correlated with the dummy variable of interest, as opposed to, perhaps, the polynomial terms of the offer price.
} 
whether offer prices that are high relative to the 52-week high specifically enjoy an increased probability of success. To ensure that $c$ identifies a true discontinuity, we control for a quartic polynomial of the offer price.

The results do indicate a discontinuous increase in the probability of target acceptance as the offer price passes the 52-week high threshold. The effect remains identifiable upon the inclusion of additional control variables that contain explanatory power for deal success, such as hostility (reducing success probability), tender (increasing), and bidder size (increasing). The magnitude of the effect is a nontrivial $3.0 \%$ to $4.3 \%$ percentage point discontinuous increase in success probability. The results are consistent with reference point behavior. ${ }^{15}$

\section{Bidders’ Announcement Returns}

We next investigate how the bidder's shareholders react to the news of bids, particularly the component that reflects the target's 52-week high. We compute the 3-day cumulative marketadjusted return at each bidder's announcement and assess its sensitivity to the offer premium

$$
r_{t-1 \rightarrow t+1}=a+b O f f e r_{i t}+e_{i t} .
$$

We start with OLS but we are more interested in IV slope estimates in which the 52-week high is used as an instrument for the offer price. In particular, we use Eq. (2) as the first stage.

Table 8 shows the results of both approaches. ${ }^{16}$ Not surprisingly, the least-squares estimates indicate that bidding shareholders react more negatively as the offer premium increases. The magnitude of this effect is not overwhelming, as the third specification indicates that a $10 \%$ increase in the offer premium is associated with a $0.2 \%$ (20 basis points) lower bidder announcement effect. One way to think about this small effect is that particularly good combinations of bidders and targets may warrant a high offer premium. If so, the market in general and bidder shareholders in particular recognize that a 10\% higher offer price does not mean $10 \%$ overpayment. Rather, the higher offer price reflects the omitted effect of deal quality.

However, bidders' shareholders are considerably more disappointed about the component of the offer price that depends on a historical reference point. The last IV regression implies that when the component of the offer premium driven by the 52 -week high increases by $10 \%$, the

\footnotetext{
${ }^{15}$ More tentatively, taking the results at face value, they would suggest that the success of between 224 and 322 out of a total 7,498 offers may have been affected by whether the offer price fell above this threshold.

${ }^{16}$ Note that the sample in Table 8 is smaller than in previous analyses because we are limited by the availability of the bidder's announcement return (recall that our sample is not limited to publicly-traded bidders, only publiclytraded targets).
} 
bidder's shareholders react with a considerable $-2.2 \%$ announcement effect relative to the average. This is large relative to the unconditional average announcement effect of $-1.5 \%$ and it is almost ten times larger than the comparable OLS estimate. ${ }^{17}$ The large difference between the OLS and IV results implies that bidder shareholders consider 52-week-high-driven bids as overpaying - and that the first stage piecewise linear specification makes an excellent instrument for pure overpayment, as opposed to simply higher offers. This distinction between the bidder shareholders and other stakeholders may reflect their greater objectivity, given that they are likely to suffer less from the anchoring or reference point utility effects of past target prices .

If we take the sensitivity of the offer premium to the 52-week high as an arbitrary transfer of value, we can take another look at the total value transfer for our sample. In the case of bidder announcement returns, there is also the possibility of an incremental value loss. The bidder return can reflect the loss to its shareholders from overpayment for this deal and also a revaluation if shareholders come to expect a bias toward overpayment in any future deals.

For each the 5,135 deals in our sample that are completed, we multiply the 52-week high by the piecewise linear coefficients $b$ in the second column of Table 3 to estimate the component of the offer premium that is driven by the 52-week high as before. We then multiply this effect on the offer premium by the coefficient $b$ in the third column of Table 8 to determine the bidder announcement return. To convert this to dollars, we multiply this quantity by the bidder market capitalization at $t-2$ to arrive at the value transferred or lost. The total is $\$ 757$ billion, $\$ 147.5$ million per deal, or 4.2 times the simple value transfer. This suggests either a market overreaction or an incremental value loss stemming from a realization that the bidder management has a tendency to overbid. Again, these economic significance calculations include only the effect of the 52-week high price, not other peak prices. However, obviously, they are subject to considerable error.

\section{Merger Waves}

We have documented that a given deal is more likely to go through if the bidder offers at least the target's 52-week high. But whether an offer appears in the first place depends on market valuations. A bidder will all else equal find it easier to pay the 52-week high when it is at a

\footnotetext{
${ }^{17}$ Our results on unconditional announcement effects resemble those of Officer (2003). See Betton et al. (2008) for a review of more than one dozen studies of bidder announcement returns - the range of results is surprisingly large.
} 
relatively small premium to current prices. A merger requires both an offer and its acceptance, so a reference point channel may help to explain the coincidence of aggregate merger waves and stock market valuations: 52-week high reference prices for targets will generally be more affordable to bidders, relative to current prices, when the market has recently done well.

Those who are most knowledgeable about merger dynamics describe precisely this mechanism. For example, in April 2010 the head of investment banking at J.P. Morgan cited several reasons to expect an increase in merger activity from prevailing levels. Among them was the fact that "the gap between buyers and sellers has narrowed. At last year's Tulane conference, Mr. Braunstein pointed out, many of the companies in the S\&P had share prices that were within $10 \%$ of the 52 -week low. Now, many of those companies are within $10 \%$ of the 52 -week high. That means sellers are more likely to believe they can get a fair value for their companies, while buyers won’t have to shell out hefty premiums to narrow the price gap” (Corkery (2010)).

To test for an effect of reference point prices on aggregate merger activity, we study quarterly data on the number of mergers from Mergerstat Review 1973 through 2007 and examine its sensitivity to the 52-week market index high price.

$$
\text { Mergers }_{t}=a+b 52 \mathrm{WkHi}_{t-30}+e_{t}
$$

We normalize the raw number of mergers by the total number of firms on the NYSE and then detrend by subtracting the average normalized level of quarterly merger activity over the trailing two and one-half year period starting before the 365 calendar days over which the market's 52week high is calculated (thus, ten data points are involved in the detrending). The Mergerstat data include all mergers involving public and private firms, so the annual total is often more than $100 \%$ of the firms on the NYSE. The 52-week market index high price, now measured at quarterly frequency, is again calculated from CRSP. Our analysis here is not meant to constitute a full investigation of all aspects of merger waves, but rather to look for any evidence that might suggest a role for peak prices. For detailed investigations of merger waves, see Rhodes-Kropf, Robinson, and Viswanathan (2004) and Harford (2005).

The first regression in Table 9 shows that the market 52-week high is a negative predictor of quarterly merger activity, consistent with the most basic prediction. Specifically, when market prices are 10 percentage points below their 52-week high, the merger rate falls by $18 \%$ relative to its trend. This fall represents $70 \%$ of the merger rate's time-series standard deviation. Panel A of Figure 5 graphs this relationship. The inverse relationship is apparent. 
We test some finer predictions. We calculate quarterly 52-week high series for high and low book-to-market portfolios using monthly returns and value-sorted portfolios constructed by Ken French. Shleifer and Vishny (2003) and Rhodes-Kropf and Viswanathan (2004) explain acquisitions in terms of market timing, with richly-valued bidders pursuing lower-valued targets, and Rhodes-Kropf et al. (2005) and Dong et al. (2006), among others, confirm that targets do indeed have higher book-to-market ratios than bidders. Forming these portfolios thus allows us, in a rough way, to separate firms that are relatively more likely to be targets from those more likely to be bidders, which allows us to add a cross-sectional dimension to the analysis. For simplicity, we refer below to low book-to-market firms as "bidders" and high book-to-market firms as "targets," while recognizing that the classifications are extremely coarse.

The next column shows that the decline in the merger rate associated with reference point prices is even stronger when one calculates the reference price of targets alone. This is shown in Panel B of Figure 5. This result is unaffected by including the contemporaneous valuation level of bidders, which is important for identifying an effect of the reference point theory incremental to the market timing theory or any other explanation that predicts merger activity is positively correlated with recent returns.

The remaining columns test further aspects of robustness. We include both the 52-week high of bidding firms and the valuation level of target firms. Consistent with predictions, these variables are unimportant in themselves and, more importantly, they do not alter inferences about the importance of bidders' reference prices. Finally, we control for lagged monthly returns, which again have no effect on key inferences. This indicates that it is the specific drop from the 52-week high that matters, not the past return over any fixed past interval. Overall, the results suggest that the reference point view helps to explain why merger waves arise and coincide with stock market valuations and recent returns.

\section{Conclusions}

We study the effect of the target's past peak prices on various aspects of merger and acquisition activity. We find that recent peak prices help to explain the bidder's offer price; bidder announcement effects; deal success; and, more speculatively, merger waves. From an allocational perspective, the effect on deal success is particularly interesting, in that it constitutes a real effect through the distribution of capital across investment opportunities. 
The results of various falsification tests and robustness tests suggest that these effects are not, as a group, easily reconciled with standard theories of mergers. Rather, we believe that the most natural explanation is that reference point prices play a role in mergers-related decisions, similar to their previously-documented roles in the contexts of real estate pricing, institutional and individual stock trading, IPO underpricing, option exercises, and other settings. 


\section{References}

Amihud, Yakov, and Baruch Lev, 1981, "Risk reduction as a managerial motive for conglomerate mergers,” Bell Journal of Economics 12, 605-617.

Andrade, Gregor, and Erik Stafford, 2001, "New evidence and perspectives on mergers," Journal of Economic Perspectives 15, 103-120.

Babcock, Linda, Xianghong Wang, and George Loewenstein, 1996, “Choosing the wrong pond: Social comparisons in negotiations that reflect a self-serving bias," Quarterly Journal of Economics 116, 1-19.

Babcock, Linda, George Loewenstein, Samuel Issacharoff, and Colin Camerer, 1995, "Biased Judgments of Fairness in Bargaining,” American Economic Review 85, 1337-1343.

Baker, Malcolm, Richard Ruback and Jeffrey Wurgler, 2007, "Behavioral corporate finance: A survey." In The Handbook of Corporate Finance: Empirical Corporate Finance vol. 1, edited by B. Espen Eckbo. New York: Elsevier/North Holland.

Baker, Malcolm, and Yuhai Xuan, 2009, "Under new management: Equity issues and the attribution of past returns,” Harvard Business School working paper.

Barberis, Nicholas, Ming Huang, and Tano Santos, 2001, "Prospect theory and asset prices," Quarterly Journal of Economics 116, 1-53.

Barberis, Nicholas, and Wei Xiong, 2009, "What drives the disposition effect? An analysis of a long-standing preference-based explanation,” Journal of Finance 64, 751-784.

Ben-David, Zahi, John Graham, and Campbell Harvey, 2007, "Managerial overconfidence and corporate policies," Duke University working paper.

Betton, Sandra, and B. Espen Eckbo, 2000, "Toeholds, bid jumps, and expected payoff in takeovers,” Review of Financial Studies 13, 841-882.

Betton, Sandra, B. Espen Eckbo, and Karin Thorburn, 2008, "Corporate takeovers," In The Handbook of Corporate Finance: Empirical Corporate Finance vol. 2, edited by B. Espen Eckbo. New York: Elsevier/North Holland.

Birru, Justin, 2009, "Confusion of confusions: A test of the disposition effect on momentum,” New York University working paper.

Boone, Audra L., and J. Harold Mulherin, 2007, “How are firms sold?” Journal of Finance 62, 847-875.

Camerer, Colin, and Ulrike Malmendier, 2007, "Behavioral economics of organizations” in: P. Diamond and H. Vartiainen (eds.), Behavioral Economics and Its Applications, Princeton University Press. 
Comment, Robert, and G. William Schwert, 1995, "Poison or placebo? Evidence on the deterrence and wealth effects of modern antitakeover measures," Journal of Financial Economics 39, 3-43.

Corkery, Michael, 2010, “Optimism? Yes. M\&A? Not Yet,” Wall Street Journal April 16, C3.

DeAngelo, Harry, Linda DeAngelo, and Edward M. Rice, 1984, “Going private: The effects of a change in corporate ownership structure,” Midland Corporate Finance Journal Summer, 35-43.

DeGeorge, Francois, Jayendu Patel, and Richard Zeckhauser, 1999, "Earnings management to exceed thresholds,” Journal of Business 72, 1-33.

Dong, Ming, David Hirshleifer, Scott Richardson, and Siew Hong Teoh, 2006, “Does investor misvaluation drive the takeover market?” Journal of Finance 61, 725-762.

Eckbo, B. Espen, and Karin Thorburn, 2008, “Corporate restructuring: Breakups and LBOs,” In The Handbook of Corporate Finance: Empirical Corporate Finance vol. 2, edited by B. Espen Eckbo. New York: Elsevier/North Holland.

Genesove, David, and Christopher Mayer, 2001, "Loss aversion and seller behavior: Evidence from the housing market,” Quarterly Journal of Economics 116, 1233-1260.

Grinblatt, Mark, and B. Han, 2005, "Prospect theory, mental accounting, and momentum," Journal of Financial Economics 78 (2), 311-339.

Grinblatt, Mark, and Matti Keloharju, 2001, “What makes investors trade?” The Journal of Finance, 56 (2), 589-616.

Harford, Jarrod, 2005, “What drives merger waves?” Journal of Financial Economics 77, 529560.

Hart, Oliver, and John Moore, 2008, “Contracts as reference points,” Quarterly Journal of Economics 123, 1-48.

Heath, Chip, Stephen Huddart, and Mark Lang, 1999, "Psychological factors and stock option exercise,” Quarterly Journal of Economics 114(2), 601-627.

Heron, Randall A., and Erik Lie, 2006, "On the use of poison pills and defensive payouts by takeover targets,” The Journal of Business 79, 1783-1807.

Huddart, Steven, Mark Lang, and Michelle H. Yetman, 2009, "Volume and price patterns around a stock’s 52-week highs and lows: Theory and evidence,” Management Science 55, 1631. 
Ivkovich, Zoran, James Poterba and Scott Weisbenner. 2005, "Tax-motivated trading by individual investors,” American Economic Review 95, 1605-30.

Jensen, Michael C., 1986, "Agency costs of free cash flow, corporate finance and takeovers," American Economic Review 76, 323-329.

Jensen, Michael C., and Richard S. Ruback, 2003, "The market for corporate control: The scientific evidence,” Journal of Financial Economics 11, 5-50.

Jovanovic, Boyan, and Peter Rousseau, 2002, “The Q-theory of mergers,” American Economic Review 92, 198-204.

Kahneman, Daniel, 1992, "Reference points, anchors, norms, and mixed feelings," Organizational Behavior and Human Decision Processes 51, 296-312.

Kahneman, Daniel, and Amos Tversky, 1979, "Prospect theory: An analysis of decision under risk,” Econometrica 47, 263-291.

Kaplan, Steven N., 1989, "Management buyouts: Evidence of taxes as a source of value," Journal of Finance 44, 611-632.

Kaplan, Steven N., ed., 2000, Mergers and Productivity, Cambridge: National Bureau of Economic Research.

Lang, Larry H.P., and René M. Stulz, 1994, “Tobin’s q, corporate diversification, and firm performance,” Journal of Political Economy 102, 1248-1280.

Lang, Larry H.P., Rene M. Stulz, and Ralph A. Walkling, 1989, "Managerial performance, Tobin's Q, and the gains from successful tender offers," Journal of Financial Economics 24, 137-154.

List, John A., 2004. "Neoclassical Theory Versus Prospect Theory: Evidence from the Marketplace,” Econometrica 72, 615-625.

List, John A., 2005, “Does market experience eliminate market anomalies?” Quarterly Journal of Economics 118, 41-71.

Ljungqvist, Alexander, and William Wilhelm, 2005, "Does prospect theory explain IPO market behavior?” Journal of Finance 60, 1759-1790.

Loughran, Tim, and Jay Ritter, "Why don't issuers get upset about leaving money on the table in IPOs?” Review of Financial Studies 15, 413-443.

Maksimovic, Vojislav, and Gordon Phillips, 2001, “The market for corporate assets: Who engages in mergers and asset sales and are there efficiency gains?” Journal of Finance 56, 2019-2065. 
Maksimovic, Vojislav, Gordon Phillips, and Nagpurnanand Prabhala, 2008, "Post-merger restructuring and the boundaries of the firm," Journal of Financial Economics, forthcoming.

Malmendier, Ulrike, and Geoffrey Tate, 2008, "Who makes acquisitions? CEO overconfidence and the market’s reaction,” Journal of Financial Economics 89(1), pp. 20-43.

Mitchell, Mark L., and Kenneth Lehn, 1990, “Do Bad Bidders Become Good Targets?” Journal of Political Economy 98, 372-398.

Morck, Randall, Andrei Shleifer, and Robert W. Vishny, 1990, "Do managerial objectives drive bad acquisitions?” Journal of Finance 45, 31-48.

Neale, Margaret Ann, and Max H. Bazerman, 1991, Cognition and rationality in negotiation. New York: The Free Press.

Northcraft, Gregory B., and Margaret Ann Neale, 1987, "Experts, amateurs, and real estate: An anchoring-and-adjustment perpective on property pricing decisions," Organizational Behavior and Human Decision Processes 39, 228-241.

Odean, Terrance, 1998, “Are investors reluctant to realize their losses?” Journal of Finance 53(5), 1775-1798.

Officer, Micah, 2003, “Termination fees in mergers and acquisitions," Journal of Financial Economics 69, 431-467.

Plott, Charles R., and Kathryn Zeiler, 2005, "The willingness to pay-willingness to accept gap, the 'endowment effect,' subject misconceptions, and experimental procedures for eliciting valuations,” American Economic Review 95, 530-545.

Polk, Christopher, and Paola Sapienza, 2009, “The stock market and corporate investment: A test of catering theory,” Review of Financial Studies 22, 187-217.

Rajan, Raghuram, Paolo Volpin, and Luigi Zingales, 2000, "The eclipse of the U.S. tire industry," in: Mergers and Productivity, Steven N. Kaplan, ed., Cambridge: National Bureau of Economic Research.

Rhodes-Kropf, Matthew, and S. Viswanathan, 2004, "Market valuation and merger waves," Journal of Finance 59, 2685-2718.

Rhodes-Kropf, Matthew, David T. Robinson, and S. Viswanathan, 2005, "Valuation waves and merger activity: The empirical evidence,” Journal of Financial Economics 77, 561-603.

Roll, Richard, 1986, “The hubris hypothesis of corporate takeovers,” Journal of Business 59, 197-216. 
Schwert, G. William, 1996, "Markup pricing in mergers and acquisitions,” Journal of Financial Economics 41, 153-192.

Shefrin, Hersh and Meir Statman, 1984, "Explaining investor preference for cash dividends," Journal of Financial Economics 13, 253-282.

Shefrin, Hersh and Meir Statman, 1985, "The disposition to sell winners too early and ride losers too long: Theory and evidence," Journal of Finance 40(3), 777-90.

Shleifer, Andrei, and Robert Vishny, 2003, "Stock market driven acquisitions," Journal of Financial Economics 70, 295-312.

Tversky, Amos, and Daniel Kahneman, 1974, "Judgement under uncertainty: Heuristics and biases," Science 185, 1124-1130. 
Table 1. Sample. The sample consists of merger or acquisition announcements. We start with 23,350 unique deals from Thomson Financial, where the announcement date is between January 1, 1984, and December 31, 2007, where the target is a public company, where the offer price is not missing, and where the bidder purchased at least $85 \%$ of the target firm shares outstanding or the percentage of shares acquired is unknown. Of these, we were able to compute 52-week high prices from CRSP for a final sample of 7,498. We have information on whether the offer is a tender offer and whether the bidder is a financial buyer from Thomson for all deals. We have information on whether the form of payment is cash, stock, or other, whether the deal is completed or withdrawn, and whether the bidder attitude is hostile, friendly, or neutral from Thomson for a subset of deals.

\begin{tabular}{|c|c|c|c|c|c|c|c|c|c|c|c|c|}
\hline \multirow[b]{2}{*}{ Year } & \multirow{2}{*}{$\begin{array}{l}\text { Total } \\
\text { Deals }\end{array}$} & \multirow{2}{*}{$\begin{array}{r}\text { Log Offer } \\
\text { Premium } \\
\%\end{array}$} & \multirow[b]{2}{*}{ Tender } & \multicolumn{3}{|c|}{ Form of Payment } & \multicolumn{2}{|c|}{ Attitude } & \multicolumn{3}{|c|}{ Completed } & \multirow[b]{2}{*}{ LBO } \\
\hline & & & & Cash & Stock & Other & Friendly & Hostile & Yes & No & $?$ & \\
\hline 1984 & 221 & 29.9 & 61 & & & & & & 115 & 97 & 9 & 3 \\
\hline 1985 & 241 & 25.5 & 67 & & & & & & 121 & 93 & 27 & 2 \\
\hline 1986 & 260 & 28.2 & 98 & & & & & & 152 & 93 & 14 & 3 \\
\hline 1987 & 284 & 27.9 & 82 & & & & & & 153 & 112 & 19 & 4 \\
\hline 1988 & 450 & 35.2 & 160 & & & & & & 219 & 194 & 34 & 8 \\
\hline 1989 & 330 & 27.0 & 94 & & & & & & 158 & 129 & 41 & 1 \\
\hline 1990 & 179 & 35.0 & 30 & & & & & & 91 & 63 & 17 & 4 \\
\hline 1991 & 135 & 38.2 & 10 & 1 & 3 & 0 & 4 & 0 & 77 & 44 & 10 & 0 \\
\hline 1992 & 149 & 33.8 & 9 & 6 & 14 & 5 & 23 & 1 & 92 & 33 & 6 & 1 \\
\hline 1993 & 201 & 32.5 & 23 & 18 & 22 & 11 & 51 & 0 & 125 & 52 & 12 & 2 \\
\hline 1994 & 285 & 30.5 & 42 & 32 & 56 & 20 & 106 & 2 & 187 & 77 & 14 & 0 \\
\hline 1995 & 357 & 29.3 & 64 & 81 & 112 & 40 & 224 & 9 & 256 & 86 & 13 & 2 \\
\hline 1996 & 375 & 27.7 & 53 & 77 & 133 & 75 & 277 & 8 & 282 & 72 & 18 & 6 \\
\hline 1997 & 473 & 27.6 & 94 & 103 & 187 & 95 & 376 & 9 & 374 & 81 & 17 & 11 \\
\hline 1998 & 520 & 28.8 & 98 & 131 & 206 & 103 & 430 & 10 & 417 & 90 & 13 & 10 \\
\hline 1999 & 612 & 34.5 & 139 & 200 & 203 & 129 & 503 & 27 & 474 & 106 & 28 & 17 \\
\hline 2000 & 516 & 37.3 & 126 & 202 & 159 & 101 & 430 & 30 & 377 & 101 & 32 & 15 \\
\hline 2001 & 334 & 38.3 & 80 & 126 & 94 & 90 & 294 & 13 & 267 & 44 & 22 & 2 \\
\hline 2002 & 229 & 33.0 & 44 & 110 & 40 & 61 & 188 & 22 & 159 & 47 & 20 & 3 \\
\hline 2003 & 237 & 27.2 & 39 & 122 & 51 & 52 & 204 & 21 & 181 & 40 & 14 & 6 \\
\hline 2004 & 221 & 22.4 & 18 & 94 & 59 & 60 & 199 & 13 & 184 & 26 & 8 & 8 \\
\hline 2005 & 256 & 22.7 & 26 & 150 & 37 & 63 & 226 & 23 & 204 & 33 & 18 & 16 \\
\hline 2006 & 313 & 22.5 & 18 & 202 & 37 & 71 & 291 & 17 & 238 & 34 & 37 & 34 \\
\hline 2007 & 320 & 21.6 & 47 & 203 & 40 & 74 & 300 & 15 & 232 & 44 & 40 & 34 \\
\hline Total & 7498 & 29.9 & 1522 & 1858 & 1453 & 1050 & 4126 & 220 & 5135 & 1791 & 483 & 192 \\
\hline
\end{tabular}


Table 2. Summary Statistics. Means, standard deviations, medians, and extreme values for the pricing of mergers and acquisitions and control variables. Panel A shows the offer premium, the 13-, 26-, 39-, 52-, 65-, 78-, 91-, and 104-week target high, and the 52week market index high. The offer premium is the offer price from Thomson expressed as a log percentage difference from the CRSP stock price 30 calendar days prior to the announcement date. The X-week target (market index) high is the X-week high stock price (market index) over the $\mathrm{X}$ weeks ending 30 days prior to the announcement date expressed as a log percentage difference from the CRSP stock price (market index) 30 calendar days prior to the announcement date. The CRSP market index is formed using total market value-weighted returns. Panel B shows two other outcome variables: whether the deal was recorded as completed from Thomson and the log bidder 3-day announcement return from CRSP centered on the announcement date from Thomson. Panel C shows control variables. The form of payment (cash, stock), the bidder attitude (hostile), the offer type (tender), and the identity of the bidder (financial buyer) are from Thomson. The target and bidder return on equity, return on assets, book-to-market equity, and earnings price ratio are from Compustat, expressed in log terms. The return on equity is defined as net income (Compustat: NI) divided by shareholders' equity (Compustat: SEQ). The return on assets is defined as net income (NI) divided by total assets (Compustat: AT). The book-to-market ratio is defined as book equity divided by market equity, where book equity is total shareholders' equity (Compustat: SEQ) plus deferred taxes and investment tax credit (Compustat: TXDITC) minus the redemption value of preferred stock (Compustat: PSRKRV) and market equity is calculated by multiplying shares outstanding (CRSP: SHROUT) and price (CRSP:PRC) at fiscal year end. The earnings price ratio is defined as earnings before interest and taxes (Compustat: EBIT) divided by market equity (ME). The target's volatility is the standard deviation of daily returns for the 365 calendar days ending 30 days prior to the announcement date from CRSP. Target market capitalization is equal to price times shares outstanding from CRSP at $t$-30. Bidder market capitalization is equal to price times shares outstanding from CRSP at $t$ - 30 . The past two-month and one-year target returns are computed ending 30 days prior to the announcement date. Continuous independent variables are Winsorized at the $1 \%$ and $99 \%$ levels.

\begin{tabular}{|c|c|c|c|c|c|c|c|}
\hline & $\mathbf{N}$ & Mean & SD & $5 \%$ & Median & $95 \%$ & Winsorized \\
\hline \multicolumn{8}{|l|}{ Panel A: Merger and Acquisition Pricing } \\
\hline Offer Premium \% & 7498 & 32.54 & 27.92 & -3.28 & 29.39 & 78.85 & No \\
\hline 13-Week Target High Price \% & 7388 & 16.20 & 19.90 & 0.12 & 9.34 & 56.62 & Yes \\
\hline 26-Week Target High Price \% & 7358 & 24.56 & 29.36 & 0.83 & 13.87 & 86.63 & Yes \\
\hline 39-Week Target High Price \% & 7296 & 30.66 & 36.49 & 1.28 & 17.33 & 106.14 & Yes \\
\hline 52-Week Target High Price \% & 7498 & 36.73 & 44.26 & 1.56 & 21.19 & 125.39 & Yes \\
\hline 65-Week Target High Price \% & 7052 & 40.24 & 47.18 & 1.68 & 23.38 & 138.29 & Yes \\
\hline 78-Week Target High Price \% & 6889 & 43.93 & 51.39 & 1.75 & 25.78 & 151.50 & Yes \\
\hline 91-Week Target High Price \% & 6746 & 46.89 & 53.69 & 1.79 & 28.35 & 160.52 & Yes \\
\hline 104-Week Target High Price \% & 6570 & 49.17 & 55.98 & 1.82 & 30.10 & 165.38 & Yes \\
\hline 52-Week Market Index High Price \% & 7498 & 6.72 & 8.53 & 0.00 & 3.19 & 26.44 & Yes \\
\hline \multicolumn{8}{|l|}{ Panel B: Other Outcome Variables } \\
\hline Completed & 6926 & 0.74 & 0.44 & 0.00 & 1.00 & 1.00 & No \\
\hline Bidder 3-day Announcement Return \% & 3937 & -1.46 & 8.25 & -14.43 & -0.81 & 9.76 & No \\
\hline \multicolumn{8}{|l|}{ Panel C: Control Variables } \\
\hline Cash & 4361 & 0.43 & 0.49 & 0.00 & 0.00 & 1.00 & No \\
\hline Stock & 4361 & 0.33 & 0.47 & 0.00 & 0.00 & 1.00 & No \\
\hline Hostile & 4361 & 0.05 & 0.22 & 0.00 & 0.00 & 1.00 & No \\
\hline Tender & 7498 & 0.20 & 0.40 & 0.00 & 0.00 & 1.00 & No \\
\hline Financial Buyer & 7498 & 0.03 & 0.16 & 0.00 & 0.00 & 0.00 & No \\
\hline Target ROE \% & 4917 & -0.23 & 40.51 & -62.63 & 7.45 & 28.58 & Yes \\
\hline Target ROA \% & 5108 & 0.86 & 26.42 & -35.03 & 6.41 & 19.14 & Yes \\
\hline Target B/M \% & 5108 & 66.11 & 74.46 & 1.64 & 48.84 & 219.69 & Yes \\
\hline Target E/P \% & 4971 & 3.33 & 45.10 & -41.67 & 3.75 & 47.18 & Yes \\
\hline log(Target Market Capitalization) & 5108 & 11.71 & 1.84 & 8.84 & 11.62 & 14.84 & Yes \\
\hline Target Volatility \% & 5108 & 3.76 & 2.08 & 1.39 & 3.29 & 7.86 & Yes \\
\hline Target 2-Month Return \% & 7498 & 0.75 & 25.00 & -43.72 & 2.25 & 37.81 & Yes \\
\hline Target 1-Year Return \% & 7498 & -4.01 & 55.04 & -105.61 & 3.91 & 70.09 & Yes \\
\hline Bidder ROE \% & 2001 & 7.05 & 32.44 & -32.89 & 10.88 & 31.61 & Yes \\
\hline Bidder ROA \% & 2048 & 3.16 & 15.63 & -14.77 & 3.75 & 20.24 & Yes \\
\hline Bidder B/M \% & 2048 & 59.30 & 81.04 & 0.60 & 36.94 & 228.46 & Yes \\
\hline Bidder E/P \% & 2029 & 11.60 & 47.03 & -13.61 & 4.30 & 74.57 & Yes \\
\hline log(Bidder Market Capitalization) & 2048 & 13.86 & 2.34 & 10.04 & 14.00 & 17.66 & Yes \\
\hline
\end{tabular}


Table 3. The Pricing of Mergers and Acquisitions. Regressions of the offer premium on the 52-week target high price. We run ordinary least squares and piecewise linear regressions.

$$
\begin{gathered}
\text { Offer }_{i t}=a+b 52 W k H i_{i, t-30}+e_{i t} \\
\text { Offer }_{i t}=a+b_{1} \min \left(52 W k H i_{i, t-30}, 25\right)+b_{2} \max \left(0, \min \left(52 W k H i_{i, t-30}-25,50\right)\right)+b_{3} \max \left(0,52 W k H i_{i, t-30}-75\right)+e_{i t}
\end{gathered}
$$

where Offer is the offer price from Thomson and $52 \mathrm{WkHi}$ is the high stock price over the 365 calendar days ending 30 days prior to the announcement date, with both expressed as a log percentage difference from the CRSP stock price $(P) 30$ calendar days prior to the announcement date. All regressions control for $1 / P$, and all ratios are expressed in log terms. Column 1 shows basic OLS results. Column 2 shows a piecewise linear regression $52 \mathrm{WkHi}$. Columns 3 and 4 replace the piecewise $52 \mathrm{WkHi}$ with the piecewise $13 \mathrm{WkHi}$ and piecewise residuals for high prices over periods greater than 13 weeks, which we label incremental effects, for example $e_{1, J}$, is estimated with the following regression:

$$
\begin{gathered}
\min \left(J W k H i_{i, t-30}, 25\right)=c+ \\
\sum_{j=13,26, \ldots}^{J-13} d_{1} \min \left(j W k H i_{i, t-30}, 25\right)+d_{2} \max \left(0, \min \left(j W k H i_{i, t-30}-25,50\right)\right)+d_{3} \max \left(0, j W k H i_{i, t-30}-75\right)+e_{1, J, i t}
\end{gathered}
$$

\begin{tabular}{|c|c|c|c|c|c|}
\hline & & OLS & Piecewise & Piecewise & Piecewise \\
\hline & & 1 & 2 & 3 & 4 \\
\hline $\begin{array}{l}\text { 52-Week Target High Price \%: } \\
b\end{array}$ & & $0.094^{* * *}$ & & & \\
\hline$b_{1}$ & & & $\begin{array}{r}0.327 * * * \\
(7.60)\end{array}$ & & \\
\hline$b_{2}$ & & & $\begin{array}{r}0.114^{* * *} \\
(3.28)\end{array}$ & & \\
\hline$b_{3}$ & & & $\begin{array}{r}0.070^{* *} \\
(2.41)\end{array}$ & & \\
\hline 13-Week Target High Price \%: & $\begin{array}{l}b_{1,13} \\
b_{2,13} \\
b_{3,13}\end{array}$ & & & $\begin{array}{r}0.415^{* * *} \\
0.157 * * \\
-0.159\end{array}$ & $\begin{array}{r}0.428^{* * *} \\
0.195^{* *} \\
-0.149\end{array}$ \\
\hline Incremental 26-Week Target High Price \% & $\begin{array}{l}b_{1,26} \\
b_{2,26} \\
b_{3,26}\end{array}$ & & & $\begin{array}{r}0.242 * * * \\
0.170 * * * \\
0.229 *\end{array}$ & $\begin{array}{r}0.291^{* * *} \\
0.134^{* *} \\
0.287^{*}\end{array}$ \\
\hline Incremental 39-Week Target High Price \% & $\begin{array}{l}b_{1,39} \\
b_{2,39} \\
b_{3,39}\end{array}$ & & & $\begin{array}{r}0.313 * * * \\
-0.028 \\
0.080\end{array}$ & $\begin{array}{r}0.350 * * * \\
0.003 \\
0.073\end{array}$ \\
\hline Incremental 52-Week Target High Price \% & $\begin{array}{l}b_{1,52} \\
b_{2,52} \\
b_{3,52}\end{array}$ & & & $\begin{array}{r}0.319 * * * \\
-0.044 \\
-0.009\end{array}$ & $\begin{array}{r}0.369 * * * \\
-0.055 \\
0.012\end{array}$ \\
\hline Incremental 65-Week Target High Price \% & $\begin{array}{l}b_{1,65} \\
b_{2,65} \\
b_{3,65}\end{array}$ & & & & $\begin{array}{l}0.154 \\
0.056 \\
0.026\end{array}$ \\
\hline Incremental 78-Week Target High Price \% & $\begin{array}{l}b_{1,78} \\
b_{2,78} \\
b_{3,78}\end{array}$ & & & & $\begin{array}{r}0.247 * * \\
-0.039 \\
-0.040\end{array}$ \\
\hline Incremental 91-Week Target High Price \% & $\begin{array}{l}b_{1,91} \\
b_{2,91} \\
b_{3,91}\end{array}$ & & & & $\begin{array}{l}0.047 \\
0.087 \\
0.040\end{array}$ \\
\hline Incremental 104-Week Target High Price \% & $\begin{array}{l}b_{1,104} \\
b_{2,104} \\
b_{3,104}\end{array}$ & & & & $\begin{array}{r}0.014 \\
0.131^{*} \\
0.023\end{array}$ \\
\hline Time Effects & & No & No & No & No \\
\hline $\begin{array}{l}\mathrm{N} \\
\mathrm{R}^{2}\end{array}$ & & $\begin{array}{r}7498 \\
0.087\end{array}$ & $\begin{array}{r}7498 \\
0.093\end{array}$ & $\begin{array}{r}7127 \\
0.100\end{array}$ & $\begin{array}{r}6503 \\
0.103\end{array}$ \\
\hline
\end{tabular}

The other residuals, $e_{2, J}$ and $e_{3, J}$, are estimated by changing the dependent variable accordingly to be the second or third part of the piecewise decomposition of the JWkHi. The coefficients $b_{1, J}, b_{2, J}, b_{3, J}$, measure the impact of adding the residuals $e_{1, J}, e_{2, J}, e_{3, J}$, to the baseline 13WkHi regression. Robust t-statistics with standard errors clustered by month are in parentheses. 
Table 4. The Pricing of Mergers and Acquisitions. Regressions of the offer premium on the 52-week target high price. We run piecewise linear regressions:

$$
\text { Offer }_{i t}=a+b_{1} \min \left(52 W k H i_{i, t-30}, 25\right)+b_{2} \max \left(0, \min \left(52 W k H i_{i, t-30}-25,50\right)\right)+b_{3} \max \left(0,52 W k H i_{i, t-30}-75\right)+e_{i t}
$$

where Offer is the offer price from Thomson and $52 \mathrm{WkHi}$ is the high stock price over the 365 calendar days ending 30 days prior to the announcement date, with both expressed as a log percentage difference from the CRSP stock price $(P) 30$ calendar days prior to the announcement date. All regressions control for $1 / P$, and all ratios are expressed in log terms. Column 1 includes controls for target past returns, measured in logs. Column 2 controls for monthly fixed effects. Column 3 repeats Column 1 of Table 3, replacing 52WkHi with the high market index price. Column 4 includes the portion of $52 \mathrm{WkHi}$ that is idiosyncratic to the market index high price in the same piecewise specification as Columns 1 and 2. Robust t-statistics with standard errors clustered by month are in parentheses.

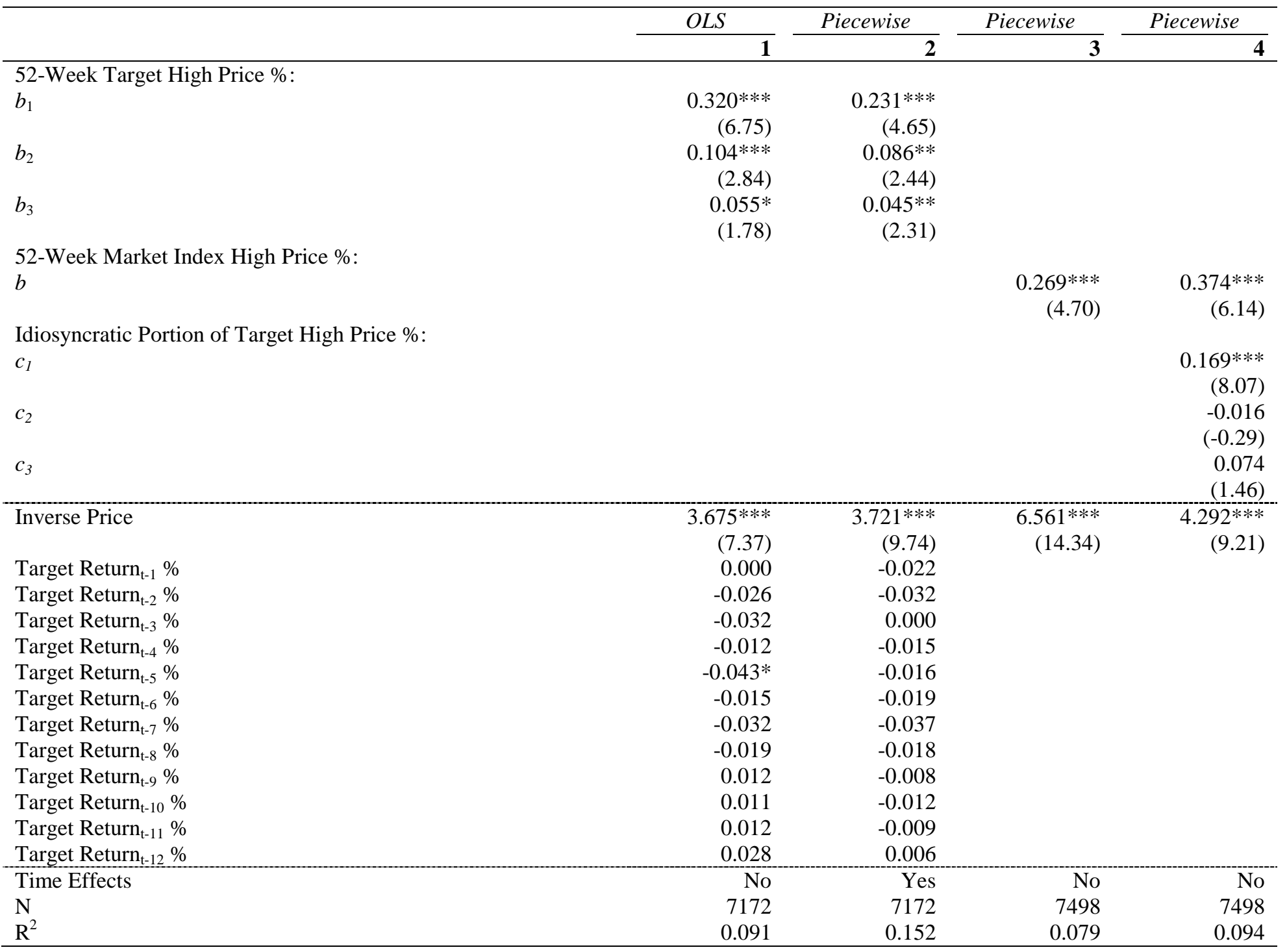


Table 5. The Pricing of Mergers and Acquisitions: Robustness. Piecewise linear regressions of the offer premium on the 52-week target high price. We run regressions:

$$
\text { Offer }_{i t}=a+b_{1} \min \left(52 W k H i_{i, t-30}, 25\right)+b_{2} \max \left(0, \min \left(52 W k H i_{i, t-30}-25,50\right)\right)+b_{3} \max \left(0,52 W k H i_{i, t-30}-75\right)+e_{i t}
$$

where Offer is the offer price from Thomson and $52 \mathrm{WkHi}$ is the high stock price over the 365 calendar days ending 30 days prior to the announcement date, with both expressed as a log percentage difference from the CRSP stock price $(P) 30$ calendar days prior to the announcement date. Column 1 is the baseline (Column 3) from Table 3. Column 2 adds deal characteristics (tender, attitude, form of payment, bidder identity) as controls to the baseline. Column 3 adds target specific controls to the baseline. Column 4 adds bidder specific financial controls to the baseline. Column 5 includes all controls. Columns 6-9 add the $x$ percentile versions of $52 W k H i$, in the same piecewise linear specification as $52 \mathrm{WkHi}$, to Column 2. All columns control for target past returns and $1 / P$, and all ratios are expressed in log terms. Robust t-statistics with standard errors clustered by month are in parentheses.

\begin{tabular}{|c|c|c|c|c|c|c|c|c|c|}
\hline & \multirow{2}{*}{$\frac{\text { Piecewise }}{1}$} & \multirow{2}{*}{$\frac{\text { Piecewise }}{2}$} & \multirow{2}{*}{$\frac{\text { Piecewise }}{3}$} & \multirow{2}{*}{$\frac{\text { Piecewise }}{\mathbf{4}}$} & \multirow{2}{*}{$\frac{\text { Piecewise }}{\mathbf{5}}$} & \multirow{2}{*}{$80 \%$} & \multirow{2}{*}{$\begin{array}{r}90 \% \\
7\end{array}$} & \multirow{2}{*}{$\begin{array}{r}95 \% \\
\mathbf{8}\end{array}$} & \multirow{2}{*}{$\begin{array}{r}99 \% \\
\mathbf{9}\end{array}$} \\
\hline & & & & & & & & & \\
\hline \multicolumn{10}{|l|}{ 52-Week Target High Price \%: } \\
\hline \multirow[t]{2}{*}{$b_{1}$} & $0.320 * * *$ & $0.328 * * *$ & $0.377^{* * *}$ & $0.399 * * *$ & $0.320 * * *$ & $0.353 * * *$ & $0.364 * * *$ & $0.483 * * *$ & $0.476^{* *}$ \\
\hline & $(6.75)$ & $(5.80)$ & (7.77) & (5.24) & (3.63) & $(4.70)$ & $(4.24)$ & (4.03) & (2.20) \\
\hline \multirow[t]{2}{*}{$b_{2}$} & $0.104^{* * *}$ & $0.0995 * *$ & $0.109 * * *$ & 0.0781 & $0.136^{* *}$ & 0.048 & 0.059 & 0.105 & 0.063 \\
\hline & $(2.84)$ & $(2.36)$ & (2.69) & $(1.38)$ & $(2.01)$ & $(1.00)$ & (1.06) & (1.43) & $(0.73)$ \\
\hline \multirow[t]{2}{*}{$b_{3}$} & $0.0547^{*}$ & $0.0751^{* *}$ & $0.0783^{* *}$ & 0.0316 & 0.0127 & -0.040 & 0.051 & 0.165 & 0.162 \\
\hline & $(1.78)$ & (2.12) & (2.32) & $(0.83)$ & $(0.23)$ & $(-0.54)$ & $(0.54)$ & $(0.83)$ & $(0.61)$ \\
\hline \multicolumn{10}{|l|}{ x-\% Target Price \%: } \\
\hline \multirow[t]{2}{*}{$c_{1}$} & & & & & & -0.010 & -0.027 & -0.155 & -0.146 \\
\hline & & & & & & $(-0.18)$ & $(-0.40)$ & $(-1.48)$ & $(-0.71)$ \\
\hline \multirow[t]{2}{*}{$c_{2}$} & & & & & & $0.108^{*}$ & 0.060 & 0.016 & 0.044 \\
\hline & & & & & & $(1.81)$ & (1.04) & $(0.23)$ & $(0.58)$ \\
\hline \multirow{2}{*}{$c_{3}$} & & & & & & 0.155 & 0.015 & -0.121 & -0.108 \\
\hline & & & & & & $(1.20)$ & $(0.10)$ & $(-0.48)$ & $(-0.35)$ \\
\hline \multirow[t]{2}{*}{ Cash } & & -0.0893 & & & 1.922 & 0.001 & -0.036 & -0.024 & -0.067 \\
\hline & & $(-0.09)$ & & & (1.12) & $(0.00)$ & $(-0.04)$ & $(-0.02)$ & $(-0.07)$ \\
\hline \multirow[t]{2}{*}{ Stock } & & 1.498 & & & 2.565 & 1.565 & 1.464 & 1.409 & 1.431 \\
\hline & & $(1.27)$ & & & (1.35) & (1.36) & (1.27) & (1.22) & (1.24) \\
\hline \multirow{2}{*}{ Hostile } & & $-3.572 * *$ & & & $9.298 * * *$ & $-3.628 * *$ & $-3.661 * *$ & $-3.579 * *$ & $-3.581 * *$ \\
\hline & & $(-2.05)$ & & & $(3.27)$ & $(-2.10)$ & $(-2.11)$ & $(-2.06)$ & $(-2.06)$ \\
\hline \multirow[t]{2}{*}{ Tender } & & $8.021^{* * *}$ & & & $4.922^{* * *}$ & $8.045^{* * *}$ & $7.995^{* * *}$ & $7.906^{* * *}$ & $7.977^{* * *}$ \\
\hline & & (7.32) & & & (2.96) & (7.26) & (7.24) & (7.14) & (7.26) \\
\hline \multirow[t]{2}{*}{ Financial Buyer } & & $-10.53^{* * *}$ & & & -6.253 & $-10.63 * * *$ & $-10.53^{* * *}$ & $-10.42 * * *$ & $-10.53 * * *$ \\
\hline & & $(-6.89)$ & & & $(-0.66)$ & $(-6.88)$ & $(-6.84)$ & $(-6.75)$ & $(-6.89)$ \\
\hline Target ROA \% & & & $\begin{array}{r}0.0352 \\
(132)\end{array}$ & & $\begin{array}{r}-0.00522 \\
(-010)\end{array}$ & & & & \\
\hline Target B/M \% & & & 0.00525 & & 0.0144 & & & & \\
\hline & & & $(0.93)$ & & (1.36) & & & & \\
\hline log(Target Market Capitalization) & & & $-1.626^{* * *}$ & & $-3.661 * * *$ & & & & \\
\hline & & & $(-5.39)$ & & $(-5.13)$ & & & & \\
\hline Target Volatility \% & & & $0.947 * *$ & & 1.170 & & & & \\
\hline & & & $(2.37)$ & & $(1.60)$ & & & & \\
\hline Bidder ROA \% & & & & $\begin{array}{r}0.0734 \\
(1.39)\end{array}$ & $\begin{array}{r}0.0314 \\
(0.34)\end{array}$ & & & & \\
\hline Bidder B/M \% & & & & -0.00219 & -0.00267 & & & & \\
\hline & & & & $(-0.29)$ & $(-0.58)$ & & & & \\
\hline log(Bidder Market Capitalization) & & & & $1.618^{* * *}$ & $1.775^{* * *}$ & & & & \\
\hline & & & & $(6.26)$ & $(4.68)$ & & & & \\
\hline Time Effects & No & No & No & No & No & No & No & No & No \\
\hline $\mathrm{N}$ & 7172 & 4152 & 5108 & 2048 & 1246 & 4152 & 4152 & 4152 & 4152 \\
\hline $\mathrm{R}^{2}$ & 0.0913 & 0.143 & 0.117 & 0.101 & 0.179 & 0.145 & 0.143 & 0.144 & 0.143 \\
\hline
\end{tabular}


Table 6. The Pricing of Mergers and Acquisitions: Subsamples. Piecewise linear regressions of the offer premium on the 52-week target high price, for subsamples. We divide the sample from Table 3 according to tender and non-tender offers, bidder attitude, and first and subsequent offers, successful and unsuccessful offers, form of payment, and first and second half of the sample period. All regressions control for $1 / P$, and all ratios are expressed in log terms. Robust t-statistics clustered by month are in parentheses.

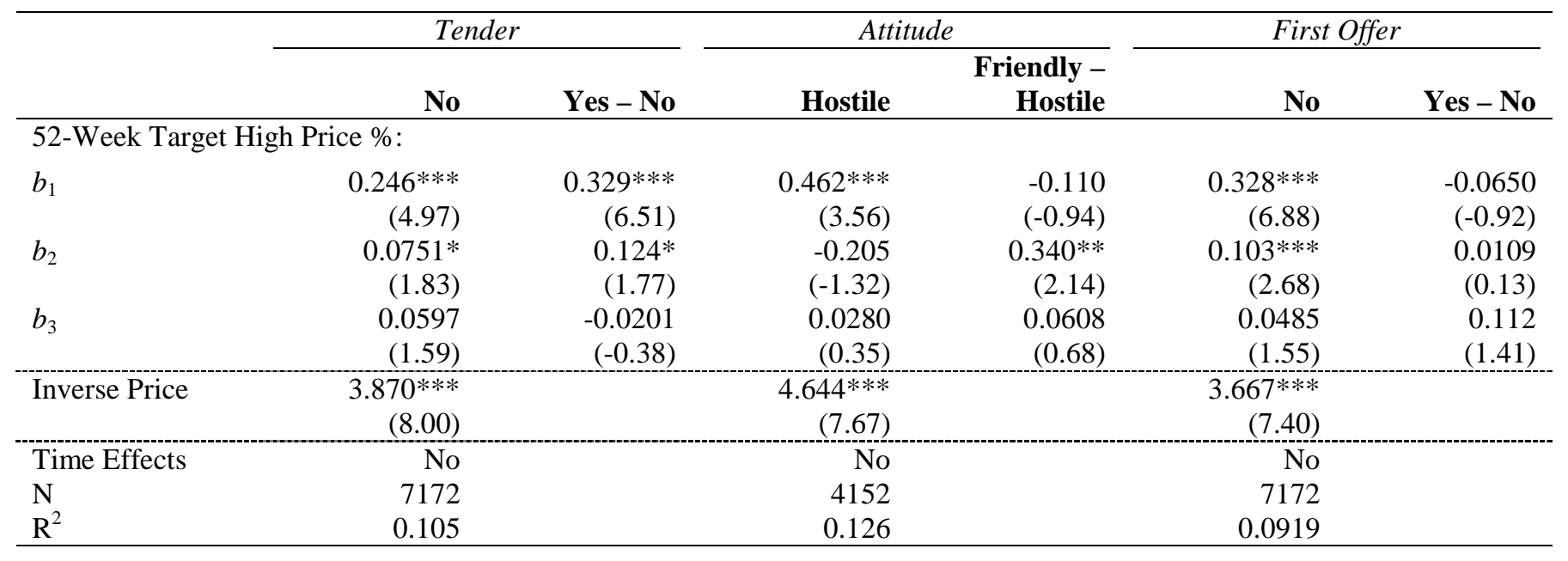

\begin{tabular}{|c|c|c|c|c|c|c|}
\hline & \multicolumn{2}{|c|}{ Successful } & \multicolumn{2}{|c|}{ Form of Payment } & \multicolumn{2}{|c|}{ Second Half } \\
\hline & No & Yes - No & Stock & Cash - Stock & No & Yes - No \\
\hline \multicolumn{7}{|c|}{ 52-Week Target High Price \%: } \\
\hline$b_{1}$ & $\begin{array}{r}0.179 * * * \\
(2.69)\end{array}$ & $\begin{array}{r}0.201 * * * \\
(3.65)\end{array}$ & $\begin{array}{r}0.450 * * * \\
(6.64)\end{array}$ & $\begin{array}{r}-0.147^{* *} \\
(-2.36)\end{array}$ & $\begin{array}{r}0.405 * * * \\
(6.89)\end{array}$ & $\begin{array}{r}-0.150 * * * \\
(-2.93)\end{array}$ \\
\hline$b_{2}$ & $\begin{array}{r}0.133^{* *} \\
(1.98)\end{array}$ & $\begin{array}{r}0.00300 \\
(0.04)\end{array}$ & $\begin{array}{r}-0.0227 \\
(-0.29)\end{array}$ & $\begin{array}{r}0.248 * * * \\
(275)\end{array}$ & $\begin{array}{r}0.0669 \\
(1.16)\end{array}$ & 0.0759 \\
\hline$b_{3}$ & $\begin{array}{r}0.0620 \\
(1.31)\end{array}$ & $\begin{array}{r}-0.00229 \\
(-0.04)\end{array}$ & $\begin{array}{r}0.0478 \\
(0.86)\end{array}$ & $\begin{array}{r}0.104^{*} \\
(1.81)\end{array}$ & $\begin{array}{r}-0.00572 \\
(-0.08)\end{array}$ & $\begin{array}{r}0.0767 \\
(1.04)\end{array}$ \\
\hline Inverse Price & $\begin{array}{r}4.021^{* * *} \\
(7.51)\end{array}$ & & $\begin{array}{r}4.307^{* * * *} \\
(6.46)\end{array}$ & & $\begin{array}{r}3.678^{* * *} \\
(7.34)\end{array}$ & \\
\hline Time Effects & No & & No & & No & \\
\hline $\mathrm{N}$ & 6635 & & 3143 & & 7172 & \\
\hline $\mathrm{R}^{2}$ & 0.109 & & 0.139 & & 0.0929 & \\
\hline
\end{tabular}


Table 7. Predicting Success in Mergers and Acquisitions. Regressions of the offer premium on the 52-week target high price. We run probit regressions:

$$
\operatorname{pr}(S)=a+b \text { Offer }_{i t}+c\left(\text { Offer }_{i t}>52 W k H i_{i, t-30}\right)+e_{i t}
$$

where $S$ is equal to 1 if a deal is completed, Offer is the offer price from Thomson and $52 W k H i$ is the high stock price over the 365 calendar days ending 30 days prior to the announcement date, with both expressed as a log percentage difference from the CRSP stock price $(P) 30$ calendar days prior to the announcement date. All regressions control for $1 / P$, and all ratios are expressed in log terms. We limit the sample only to those deals that Thomson identifies as completed or withdrawn. The first two columns estimate a linear relationship between the probability of success and the offer premium. The second two columns use a flexible polynomial. Robust t-statistics with standard errors clustered by month are in parentheses.

\begin{tabular}{|c|c|c|c|c|}
\hline & Probit & Probit & Probit & Probit \\
\hline & 1 & 2 & 3 & 4 \\
\hline Offer Premium: & & & & \\
\hline$b$ & $0.00109 * * *$ & 0.000103 & 0.00116 & 0.000783 \\
\hline & (3.28) & $(0.64)$ & $(1.03)$ & $(1.50)$ \\
\hline Offer Premium $^{2}$ & & & 0.00000179 & -0.00000760 \\
\hline & & & $(0.08)$ & $(-0.73)$ \\
\hline Offer Premium ${ }^{3}$ & & & 0.000000232 & 0.000000105 \\
\hline & & & $(0.51)$ & $(-0.67)$ \\
\hline Offer Premium ${ }^{4}$ & & & $-3.86 \mathrm{e}-09$ & $9.93 \mathrm{e}-10$ \\
\hline & & & $(-0.78)$ & $(0.48)$ \\
\hline Offer Premium>52-Week Target $\mathrm{F}$ & & & & \\
\hline c & $0.0431 * * *$ & $0.0319 * * *$ & $0.0425 * * *$ & $0.0297 * * *$ \\
\hline & $(2.87)$ & (3.07) & $(2.75)$ & $(2.86)$ \\
\hline Cash & & -0.0133 & & -0.0141 \\
\hline & & $(-1.18)$ & & $(-1.24)$ \\
\hline Stock & & 0.00935 & & 0.0101 \\
\hline & & $(1.17)$ & & $(1.27)$ \\
\hline Hostile & & $-0.454^{* * *}$ & & $-0.453^{* * *}$ \\
\hline & & $(-6.23)$ & & $(-6.22)$ \\
\hline Tender & & $0.0251^{* * *}$ & & $0.0252^{* * *}$ \\
\hline & & (3.59) & & (3.67) \\
\hline log(Target Market Capitalization) & & $-0.0107 * * *$ & & $-0.0108 * * *$ \\
\hline & & $(-3.74)$ & & $(-3.70)$ \\
\hline $\log$ (Bidder Market Capitalization) & & $0.00587 * * *$ & & $0.00580 * * *$ \\
\hline & & $(3.28)$ & & (3.26) \\
\hline Inverse Price & -0.0110 & -0.00978 & -0.0101 & -0.00908 \\
\hline & $(-1.48)$ & $(-1.64)$ & $(-1.34)$ & $(-1.52)$ \\
\hline Target Return $_{\mathrm{t}-1} \%$ & 0.000230 & -0.000181 & 0.000219 & -0.000194 \\
\hline Target Return $_{\mathrm{t}-2} \%$ & $0.00155^{* * *}$ & 0.000114 & $0.00152^{* * *}$ & 0.0000859 \\
\hline Target Return $_{\mathrm{t}-3} \%$ & $0.00118^{* * *}$ & 0.0000122 & $0.00117 * * *$ & 0.00000775 \\
\hline Target Return $_{\mathrm{t}-4} \%$ & $0.000870^{* * *}$ & -0.000151 & $0.000842 * *$ & -0.000145 \\
\hline Target Return $_{\mathrm{t}-5} \%$ & -0.000536 & $0.000384 * *$ & -0.000560 & $0.000370^{* *}$ \\
\hline Target Return $_{\mathrm{t}-6} \%$ & 0.000620 & 0.000301 & 0.000600 & 0.000277 \\
\hline Target Return $_{\mathrm{t}-7} \%$ & 0.000591 & -0.0000365 & 0.000579 & -0.0000409 \\
\hline Target Return $_{\mathrm{t}-8} \%$ & -0.000209 & -0.0000556 & -0.000214 & -0.0000691 \\
\hline Target Return $_{\mathrm{t}-9} \%$ & -0.000246 & 0.0000338 & -0.000267 & 0.00000176 \\
\hline Target Return $_{\mathrm{t}-10} \%$ & -0.000480 & 0.000137 & -0.000500 & 0.000129 \\
\hline Target Return $_{\mathrm{t}-11} \%$ & -0.000567 & 0.000253 & -0.000566 & 0.000244 \\
\hline Target Return $_{\mathrm{t}-12} \%$ & 0.0000920 & 0.000342 & 0.0000666 & 0.000336 \\
\hline Time Effects & No & No & No & No \\
\hline $\mathrm{N}$ & 6635 & 2355 & 6635 & 2355 \\
\hline $\mathrm{R}^{2}$ & 0.0148 & 0.206 & 0.0151 & 0.209 \\
\hline
\end{tabular}


Table 8. Mergers and Acquisitions: Market Reaction. Ordinary and two-stage least squares regressions of the 3-day CAR of the bidder on the offer premium:

$$
r_{t-1 \rightarrow t+1}=a+b O f f e r_{i t}+e_{i t} \quad \text { Offer }_{i t}=a+b_{1} \min \left(52 W k H i_{i, t-30}, 25\right)+b_{2} \max \left(0, \min \left(52 W k H i_{i, t-30}-25,50\right)\right)+b_{3} \max \left(0,52 W k H i_{i, t-30}-75\right)+e_{i t}
$$

where $r$ is the market-adjusted return of the bidder for the three-day period centered on the announcement date, Offer is the offer price from Thomson and $52 W k H i$ is the high stock price over the 365 calendar days ending 30 days prior to the announcement date, with both expressed as a log percentage difference from the CRSP stock price 30 calendar days prior to the announcement date. The first, second, and fourth columns use ordinary least squares. The third and the fifth columns instrument for the offer premium using $52 W k H i$. Robust tstatistics with standard errors clustered by month are in parentheses.

\begin{tabular}{|c|c|c|c|c|c|}
\hline & \multicolumn{2}{|l|}{ OLS } & \multicolumn{2}{|r|}{ OLS } & $I V$ \\
\hline & 1 & $\overline{2}$ & 3 & 4 & 5 \\
\hline \multicolumn{6}{|l|}{ Offer Premium: } \\
\hline$b$ & $\begin{array}{r}-0.0186 * * * \\
(-2.64)\end{array}$ & $\begin{array}{r}-0.0204 * * * \\
(-2.74)\end{array}$ & $\begin{array}{r}-0.215^{* * *} \\
(-3.48)\end{array}$ & $\begin{array}{r}-0.0443 * * * \\
(-4.21)\end{array}$ & $\begin{array}{r}-0.253^{* * *} \\
(-4.39)\end{array}$ \\
\hline \multirow[t]{2}{*}{ Cash } & & & & $1.421^{* * *}$ & $1.749 * * *$ \\
\hline & & & & $(3.76)$ & $(3.59)$ \\
\hline \multirow[t]{2}{*}{ Stock } & & & & $-1.831 * * *$ & $-1.380 * * *$ \\
\hline & & & & $(-5.14)$ & $(-3.37)$ \\
\hline \multirow{2}{*}{ Hostile } & & & & -0.229 & 1.249 \\
\hline & & & & $(-0.25)$ & $(1.07)$ \\
\hline \multirow[t]{2}{*}{ Tender } & & & & $1.124 * * *$ & $2.560 * * *$ \\
\hline & & & & (3.10) & (4.06) \\
\hline \multirow[t]{2}{*}{ Financial Buyer } & & & & 3.185 & 0.704 \\
\hline & & & & $(1.56)$ & $(0.20)$ \\
\hline \multirow[t]{2}{*}{ log(Target Market Capitalization) } & & & & $-1.073^{* * *}$ & $-1.532^{* * *}$ \\
\hline & & & & $(-7.26)$ & $(-6.85)$ \\
\hline \multirow[t]{2}{*}{ log(Bidder Market Capitalization) } & & & & $0.386 * * *$ & $0.729 * * *$ \\
\hline & & & & $(4.06)$ & $(4.97)$ \\
\hline \multirow[t]{2}{*}{ Inverse Price } & $0.320 * *$ & $0.614^{* * *}$ & $1.412^{* * *}$ & $-0.651^{* *}$ & -0.0215 \\
\hline & $(2.00)$ & (3.38) & (4.19) & $(-2.43)$ & $(-0.06)$ \\
\hline Target Return $_{\mathrm{t}-1} \%$ & & -0.00159 & -0.00970 & 0.00413 & -0.00922 \\
\hline \multicolumn{2}{|l|}{ Target Return $_{\mathrm{t}-2} \%$} & -0.00846 & -0.0120 & -0.00641 & -0.00538 \\
\hline \multicolumn{2}{|l|}{ Target Return $_{\mathrm{t}-3} \%$} & -0.00261 & $-0.0225^{*}$ & 0.00799 & -0.00121 \\
\hline \multicolumn{2}{|l|}{ Target Return $_{\mathrm{t}-4} \%$} & 0.00875 & -0.00298 & -0.00436 & -0.0161 \\
\hline \multicolumn{2}{|l|}{ Target Return $_{\mathrm{t}-5} \%$} & $0.0201 *$ & 0.00549 & -0.00247 & -0.0211 \\
\hline \multicolumn{2}{|l|}{ Target Return $_{\mathrm{t}-6} \%$} & 0.0166 & 0.0152 & 0.0113 & 0.0121 \\
\hline \multicolumn{2}{|l|}{ Target Return $_{\mathrm{t}-7} \%$} & 0.0128 & 0.00454 & 0.00307 & -0.00539 \\
\hline \multicolumn{2}{|l|}{ Target Return $_{\mathrm{t}-8} \%$} & 0.00737 & -0.00922 & 0.00277 & -0.0142 \\
\hline \multicolumn{2}{|l|}{ Target Return ${ }_{\mathrm{t}-9} \%$} & $0.0231 *$ & 0.0187 & 0.0207 & 0.0114 \\
\hline \multicolumn{2}{|l|}{ Target Return ${ }_{\mathrm{t}-10} \%$} & $0.0268 * *$ & 0.0211 & 0.0117 & 0.00794 \\
\hline \multicolumn{2}{|l|}{ Target Return $_{\mathrm{t}-11} \%$} & 0.0174 & 0.0195 & 0.00294 & 0.00136 \\
\hline \multicolumn{2}{|l|}{ Target Return ${ }_{\mathrm{t}-12} \%$} & 0.0139 & 0.00686 & 0.0222 & 0.0133 \\
\hline \multirow{3}{*}{$\begin{array}{l}\text { Time Effects } \\
\mathrm{N} \\
\mathrm{R}^{2}\end{array}$} & 3937 & 3750 & 3750 & 2400 & 2400 \\
\hline & No & No & No & No & No \\
\hline & 0.00301 & 0.0129 & . & 0.0873 & . \\
\hline
\end{tabular}


Table 9. Merger Waves. Regressions of the number of mergers on the 52-week high of different indices. We run ordinary least squares regressions.

$$
\text { Mergers }_{t}=a+b 52 \mathrm{WkHi}_{t-30}+e_{t}
$$

where Mergers is a normalized measure of merger activity, and $52 \mathrm{WkHi}$ is the high stock price for the market over the 365 calendar days prior to the quarter for which the number of mergers is reported. Quarterly data on the raw number of mergers are from Mergerstat Review for the period 1973-2007. The quarterly levels of merger activity are calculated by dividing the raw number of mergers each quarter by the total number of firms on the NYSE, as reported by CRSP. Detrended quarterly levels of merger activity are calculated by subtracting the average level of quarterly merger activity over the trailing two and one-half year period before the 365 calendar days over which the high stock price is calculated from the current quarterly level of merger activity. The 52-week market index high price is calculated from CRSP (CRSP: TOTVAL). The 52-week high B/M and low B/M index high prices are calculated from proxies indices formed from the monthly returns in Ken French's "Portfolios Formed on Book-to-Market.” High B/M is defined as the top 30\% of French's $\mathrm{B} / \mathrm{M}$-ranked universe; low $\mathrm{B} / \mathrm{M}$ is defined as the bottom 30\%. Robust t-statistics with standard errors that correct for autocorrelation up to five lags are in parentheses.

\begin{tabular}{|c|c|c|c|c|c|c|c|}
\hline & 1 & 2 & 3 & 4 & 5 & 6 & 7 \\
\hline $\begin{array}{l}\text { 52-Week Market Index High Price \%: } \\
b\end{array}$ & $\begin{array}{r}-0.0181 * * * \\
(-3.03)\end{array}$ & & & & & & \\
\hline $\begin{array}{l}\text { 52-Week High B/M Index High Price \%: } \\
b\end{array}$ & & $\begin{array}{r}-0.0229 * * * \\
(-5.09)\end{array}$ & $\begin{array}{r}-0.0258 * * * \\
(-6.34)\end{array}$ & $\begin{array}{r}-0.0216^{* * * *} \\
(-4.21)\end{array}$ & $\begin{array}{r}-0.0351 * * \\
(-2.19)\end{array}$ & $\begin{array}{r}-0.0349 * * * \\
(-2.86)\end{array}$ & $\begin{array}{r}-0.0283 * * \\
(-2.08)\end{array}$ \\
\hline $\begin{array}{l}\text { 52-Week Low B/M Index High Price \%: } \\
b\end{array}$ & & & & $\begin{array}{r}-0.00370 \\
(-0.57) \\
\end{array}$ & & & $\begin{array}{r}-0.00962 \\
(-1.12) \\
\end{array}$ \\
\hline $\mathrm{B} / \mathrm{M}$ of High B/M Index: & & & & $\begin{array}{l}-0.189 \\
(-0.65)\end{array}$ & & & $\begin{array}{r}0.0478 \\
(0.15)\end{array}$ \\
\hline B/M of Low B/M Index: & & & $\begin{array}{r}-2.101 * * * \\
(-3.80) \\
\end{array}$ & $\begin{array}{r}-1.670^{*} \\
(-1.75)\end{array}$ & & $\begin{array}{r}-2.128 * * * \\
(-3.76) \\
\end{array}$ & $\begin{array}{r}-2.244^{* *} \\
-(-2.22) \\
\end{array}$ \\
\hline 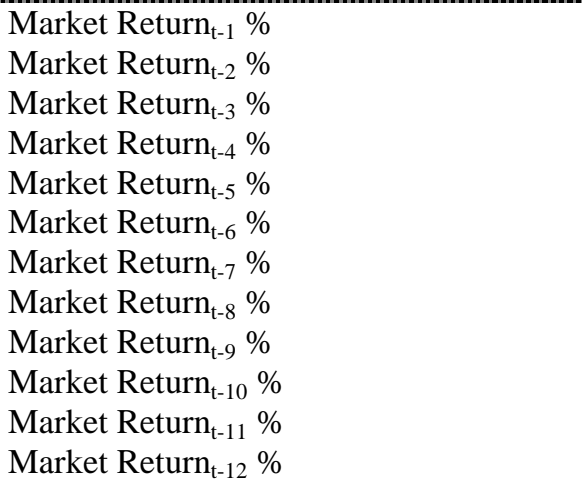 & & & & & $\begin{array}{r}-0.0108 \\
-0.00900 \\
-0.0142 \\
0.00678 \\
0.00134 \\
-0.0170 \\
0.00687 \\
0.00910 \\
-0.0157 \\
0.0147 \\
-0.00528 \\
0.000162\end{array}$ & $\begin{array}{r}-0.00937 \\
-0.000946 \\
-0.0131 \\
0.00897 \\
0.00863 \\
-0.0134 \\
0.00743 \\
0.0151 \\
-0.0139^{*} \\
0.0183 \\
-0.00346 \\
-0.000119\end{array}$ & $\begin{array}{r}-0.0141 \\
-0.00227 \\
-0.0141 \\
0.00881 \\
0.00848 \\
-0.0147 \\
0.00841 \\
0.0157 \\
-0.0156^{*} \\
0.0196 \\
-0.00299 \\
0.000826\end{array}$ \\
\hline $\begin{array}{l}\mathrm{N} \\
\mathrm{R}^{2}\end{array}$ & $\begin{array}{r}126 \\
0.1005\end{array}$ & $\begin{array}{r}126 \\
0.0991\end{array}$ & $\begin{array}{r}126 \\
0.3239\end{array}$ & $\begin{array}{r}126 \\
0.3357\end{array}$ & $\begin{array}{r}126 \\
0.1640\end{array}$ & $\begin{array}{r}126 \\
0.3886\end{array}$ & $\begin{array}{r}126 \\
0.4045\end{array}$ \\
\hline
\end{tabular}


Figure 1. Slide from Cablevision Presentation to Shareholders, October 24, 2007. The management of Cablevision recommended acceptance of a $\$ 36.26$ per share cash bid from the Dolan family. The slide compares this bid price to various recent prices including 52-week highs.

\section{Valuation Achieved}

\section{Market Premia}

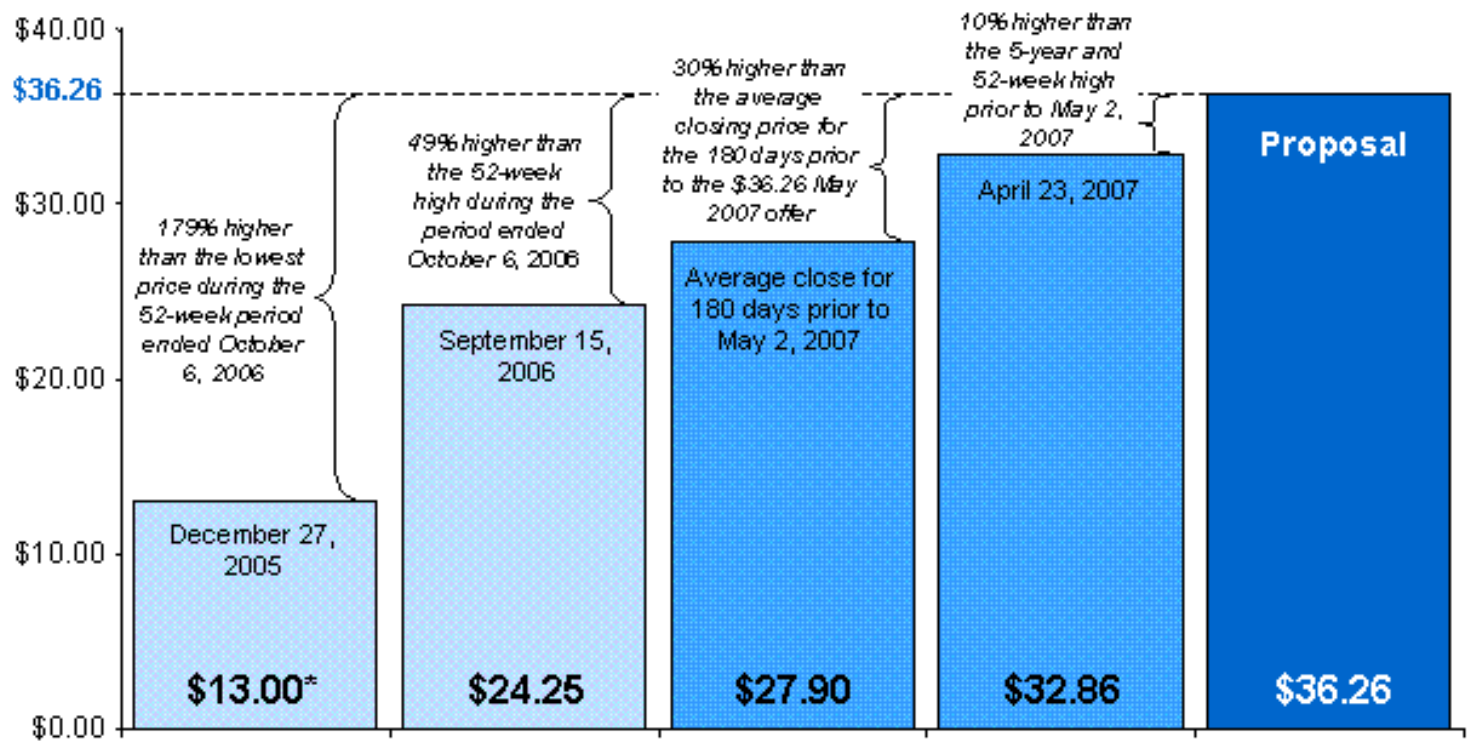

* Adjusted to reflect payment of $\$ 10 /$ share special dividend. 
Figure 2. Offer Price Density. Histogram of the difference between the offer price and the target's 52-week high price, where Offer is the offer price from Thomson and $52 \mathrm{WkHi}$ is the high stock price over the 365 calendar days ending 30 days prior to the announcement date, with both expressed as a log percentage difference from the CRSP stock price 30 calendar days prior to the announcement date.

Panel A: 13-Week High

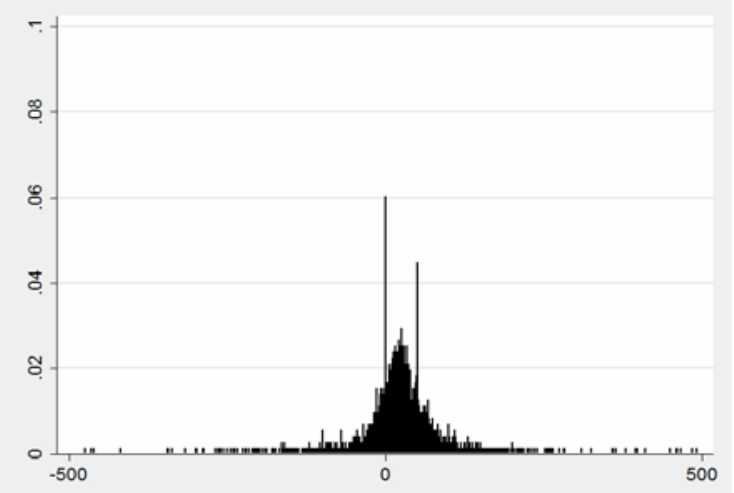

Panel C: 39-Week High

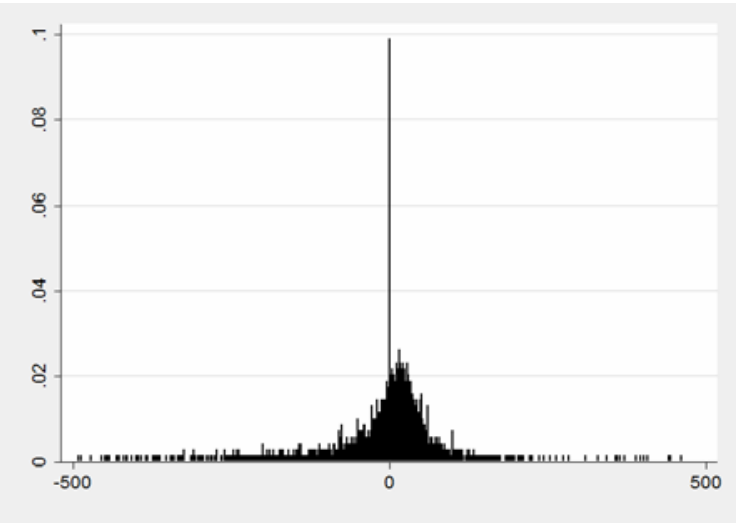

Panel B: 26-Week High

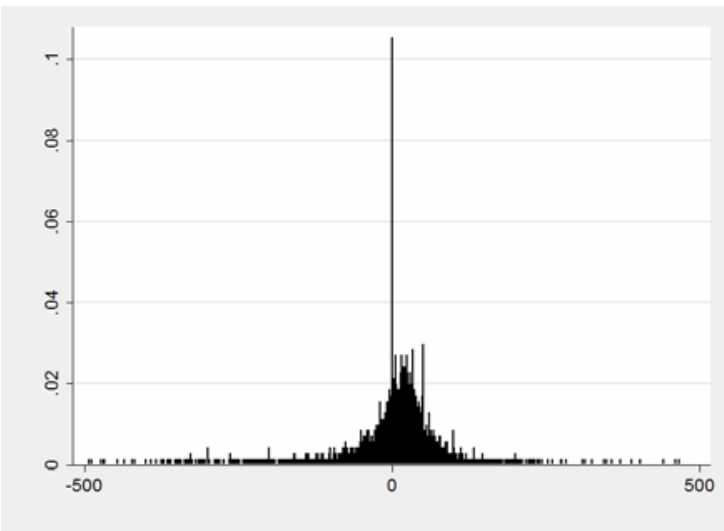

Panel D: 52-Week High

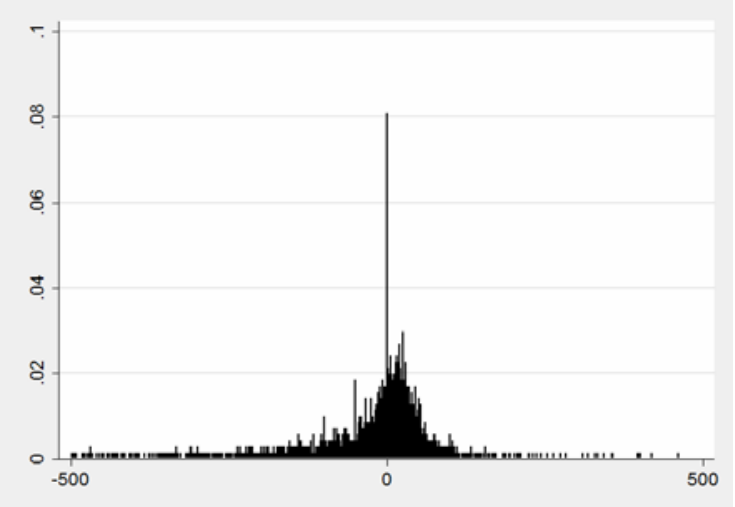

Panel E: 104-Week High

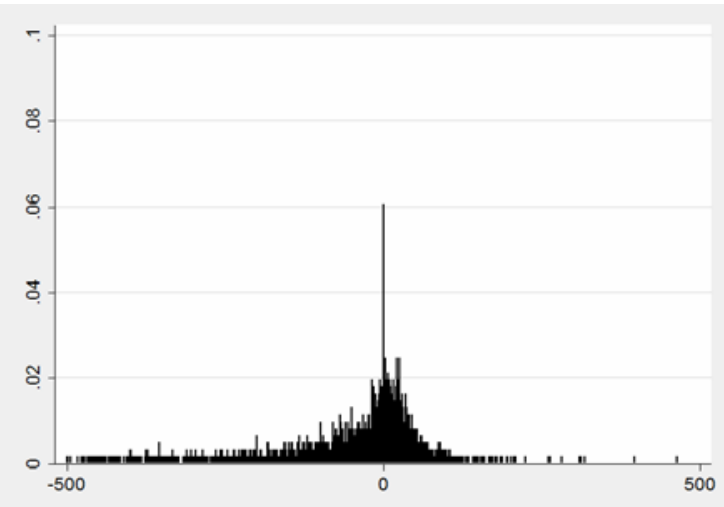


Figure 3. Offer Price Density: Discontinuity at the 52-week high. Histogram of the difference between the offer price and the target's 52-week high price, where Offer is the offer price from Thomson and $52 \mathrm{WkHi}$ is the high stock price over the 365 calendar days ending 30 days prior to the announcement date, with both expressed as a $\log$ percentage difference from the CRSP stock price 30 calendar days prior to the announcement date. Panel A uses 500 bins, while Panel B uses 200 bins. The discontinuities are statistically significant with bootstrap p-values of 0.01 and 0.00 respectively, using the approach described in Nicholas (2007).

Panel A: 500 bins of the offer price, centered at the 52-week high

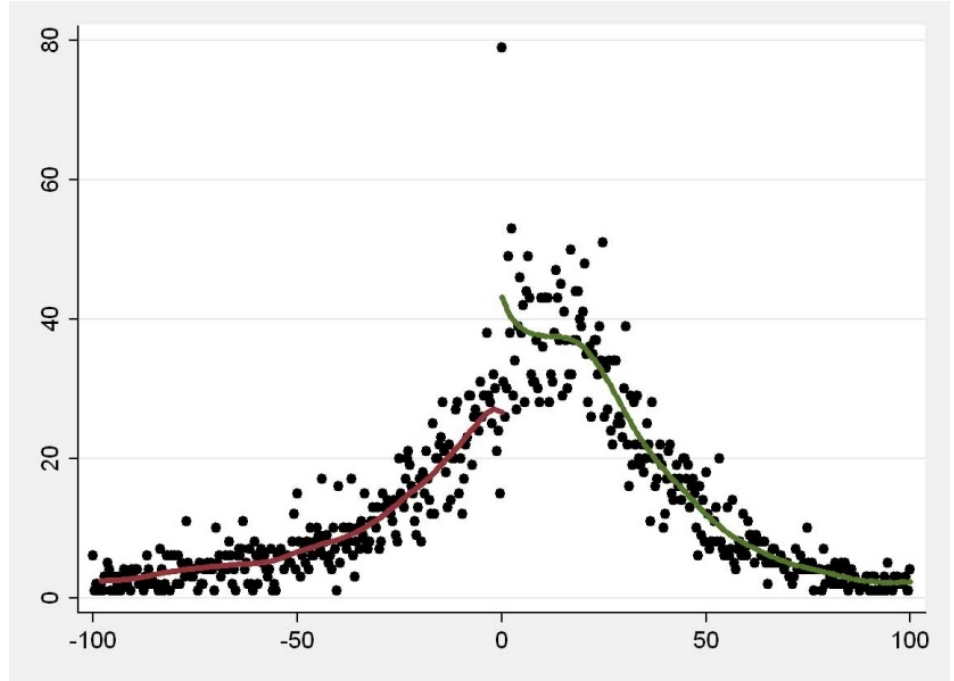

Panel B: 200 bins of the offer price, centered at the 52-week high

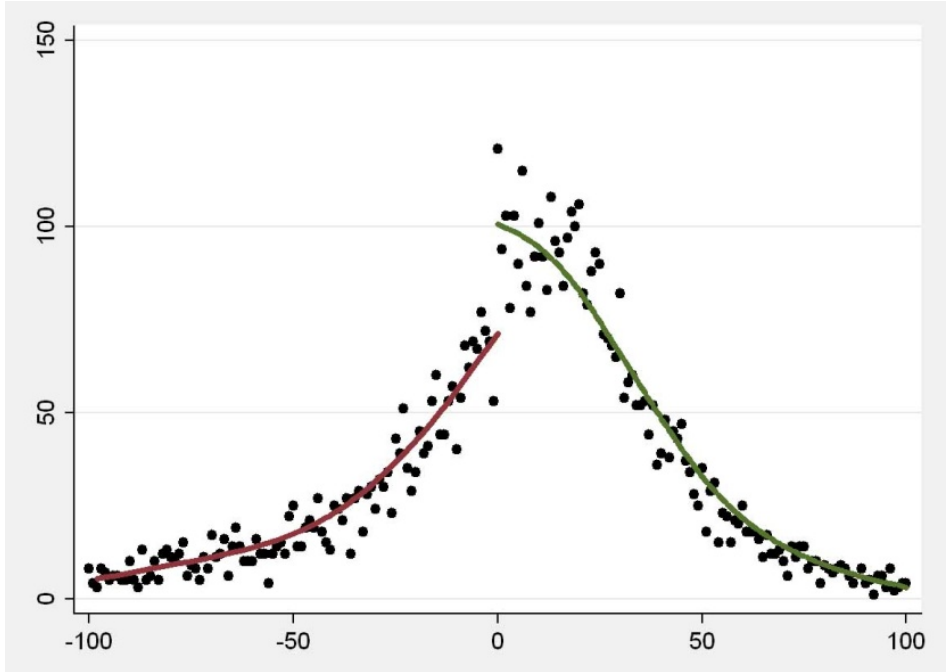


Figure 4. Non-linear effects. Gaussian kernel regressions of the offer premium on the 52-week target high price.

$$
\text { Offer }_{i t}=a+b 52 W k H i_{i, t-30}+e_{i t}
$$

where Offer is the offer price from Thomson and $52 \mathrm{WkHi}$ is the high stock price over the 365 calendar days ending 30 days prior to the announcement date, with both expressed as a log percentage difference from the CRSP stock price 30 calendar days prior to the announcement date. The first kernel regression has a bandwidth of 20 and has 40 estimation points. The second has a bandwidth and 40 estimation points. Panel A limits the sample to situations where the 52-week high is less than 1.5 times the target price 30-days prior to the announcement date. Panel B limits the sample to situations where the 52-week high is less than two times the target price 30-days prior to the announcement date.

Panel A. Acquisition premium (y-axis) on the 52-week high premium (x-axis), 0 to 50

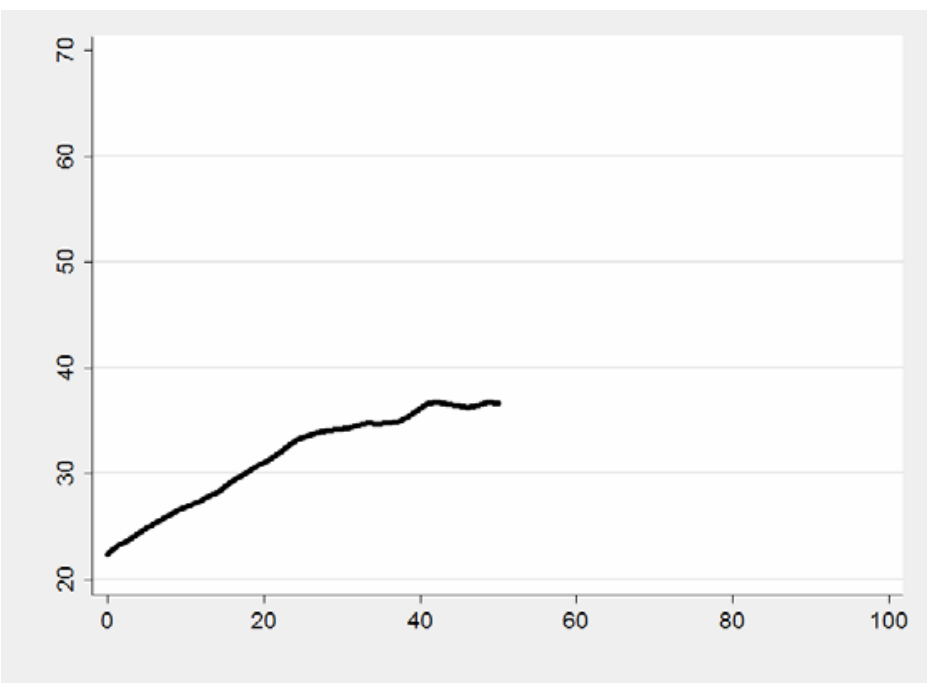

Panel B. Acquisition premium (y-axis) on the 52-week high premium (x-axis), 0 to 100

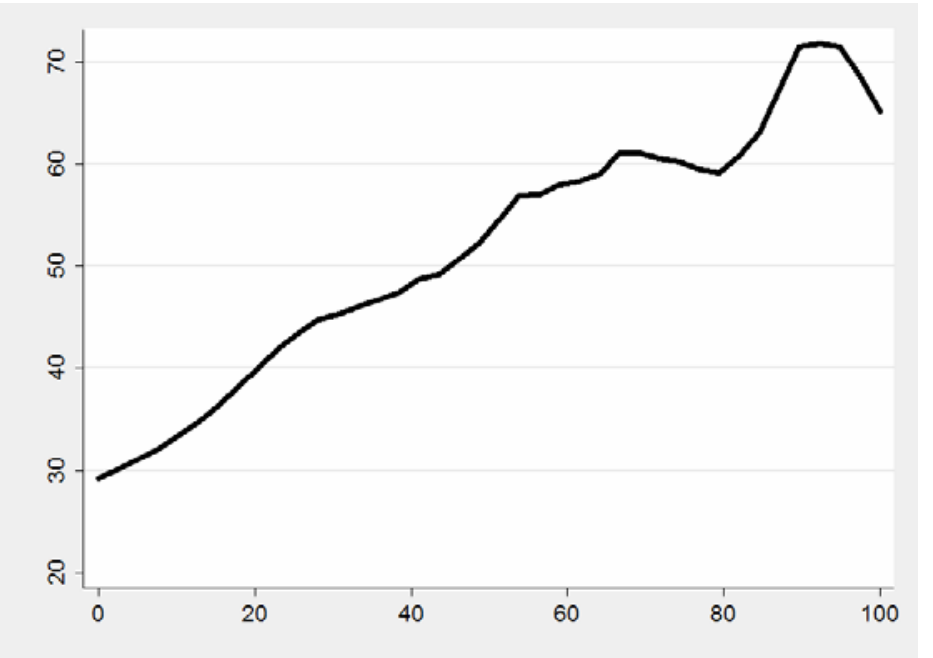


Figure 5. Merger Waves. Quarterly data on the raw number of mergers are from Mergerstat Review for the period 1973-2007. The quarterly levels of merger activity are calculated by dividing the raw number of mergers each quarter by the total number of firms on the NYSE, as reported by CRSP. Detrended quarterly levels of merger activity are calculated by subtracting the average level of quarterly merger activity over the trailing two and one-half year period before the 365 calendar days over which the high stock price is calculated from the current quarterly level of merger activity. The 52-week market index high price is calculated from CRSP (CRSP: TOTVAL). The 52week high $\mathrm{B} / \mathrm{M}$ and low $\mathrm{B} / \mathrm{M}$ index high prices are calculated from proxies indices formed from the monthly returns in Ken French's "Portfolios Formed on Book-to-Market." High B/M is defined as the top 30\% of French's B/Mranked universe; low $\mathrm{B} / \mathrm{M}$ is defined as the bottom $30 \%$.

Panel A. Plot of detrended quarterly level of merger activity (solid, left y-axis) and the 52-week high of the market index (dashed, right y-axis)

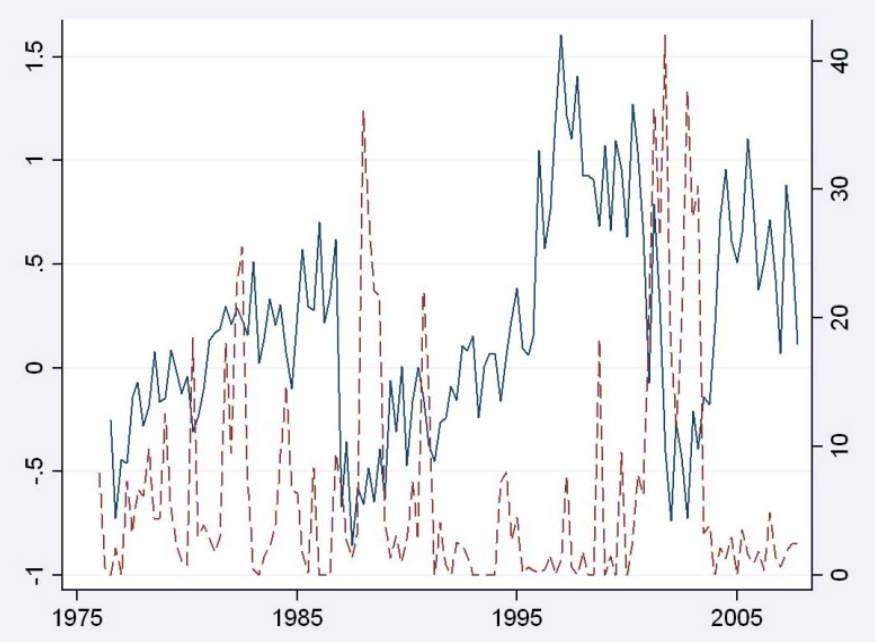

Panel B. Plot of detrended quarterly level of merger activity (solid, left y-axis) and the 52-week high of the high $\mathrm{B} / \mathrm{M}$ index (dashed, right $\mathrm{y}$-axis)

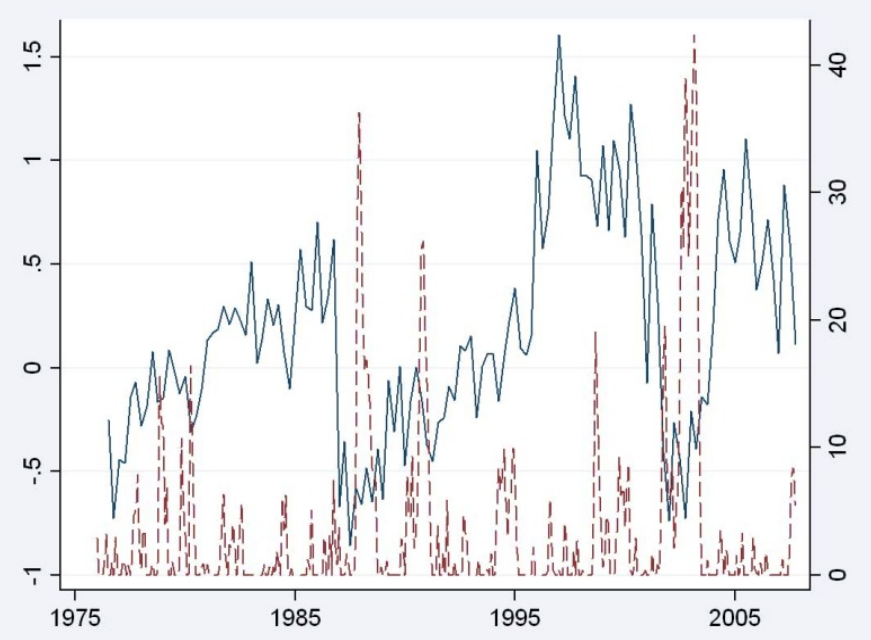

